$1-1-1966$

\title{
Rural industrialization : a case study in educational values and attitudes
}

Leonard Marion Sizer

William B. Clifford

Follow this and additional works at: https://researchrepository.wvu.edu/ wv_agricultural_and_forestry_experiment_station_bulletins

\section{Digital Commons Citation}

Sizer, Leonard Marion and Clifford, William B., "Rural industrialization : a case study in educational values and attitudes" (1966). West Virginia Agricultural and Forestry Experiment Station Bulletins. 521.

https://researchrepository.wvu.edu/wv_agricultural_and_forestry_experiment_station_bulletins/481 @ WVU. It has been accepted for inclusion in West Virginia Agricultural and Forestry Experiment Station Bulletins by an authorized administrator of The Research Repository @WVU. For more information, please contact ian.harmon@mail.wvu.edu. 
West Virginia University Libraries

|| || || || || |||||| ||| || || || || || || || || 
Digitized by the Internet Archive in 2010 with funding from

Lyrasis Members and Sloan Foundation 
RURAL

WDUSTRIALIZATION:

ACase Study in Educational Values and Attitudes

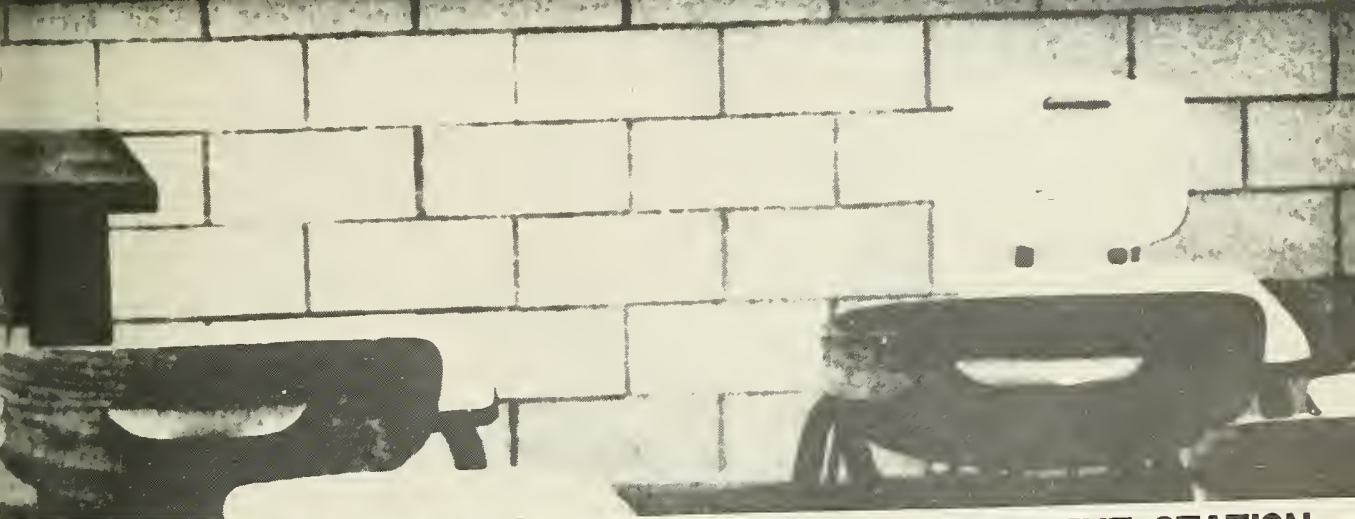

WEST VIRGINIA UNIVERSTTY AGRICULTURAL EXPERIMENT STATION

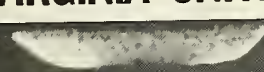





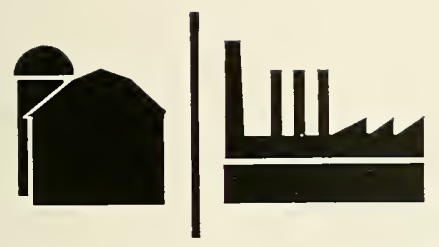

RURAL INDUSTRIALIZATION:

\section{A Case Study in Educational Values and Attitudes}

Leonard M. Sizer and William B. Clifford 


\section{THE AUTHORS}

Leonard M. Sizer is Rural Sociologist; William B. Clifford was a Research Technician at the time of the study. He is now a Graduate Assistant in the Department of Rural Sociology, University of Kentucky.

\section{ACKNOWLEDGMENTS}

The authors wish to acknowlectge their appreciation for the assistance given by Dr. Harold A. Gibbard, Chairman of the Department of Sociology, in developing the structure and analysis of the field study and to Dr. Homer C. Evans, Assistant Director of the Agricultural Experiment Station, for his helpful suggestions regarding the study.

The atuthors, also, wish to express their appreciation to the people of Jackson County for their thorough and cheerful cooperation.

WEST VIRGINIA UNIVFRSITY

Agricultural Experinilint Station

College of Agriculture and Forestry

A. H. VanLanidinghan, Director

MORGANTOWN 


\section{TABLE OF CONTENTS}

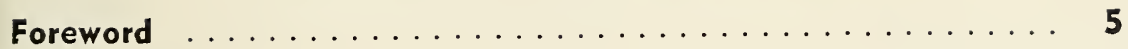

Introduction $\ldots \ldots \ldots \ldots \ldots \ldots \ldots \ldots \ldots \ldots \ldots$

Jackson County in Perspective ............... 8

Comparison of Jackson and Roane Counties .......... 9

Problem, Procedure and Methodology ............ 10

Characteristics of the Sample ............... 15

Attitudes of the Total Sample Toward Education and the Schools

Attitudes of Parents of School Pupils Toward

Education and the Schools

Introduction of Intervening Variables ........... 31

Participation in School Activities of the Total Sample . . . . . . 34

Participation in School Activities by Parents of School Pupils . . 36

Introduction of Intervening Variables .......... 38

Respondents' Awareness .................. 40

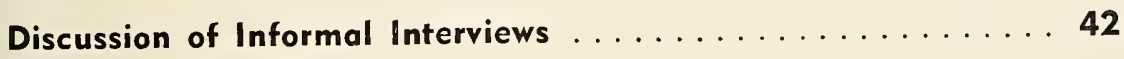

Respondents' Opinions About People's Attitudes
Toward the Schools $\ldots \ldots \ldots \ldots \ldots \ldots \ldots \ldots \ldots \ldots$

Conclusions $\ldots \ldots \ldots \ldots \ldots \ldots \ldots \ldots \ldots \ldots \ldots \ldots \ldots$ 



\section{FOREWORD}

This study of Jackson County is focused upon the comparison of the educational attitudes and values of old residents and in-migrants. The study needs to be viewed in a context of two distinct perspectives. First, interest in and concern for the local education enterprise has intensified in the nation as a whole, quite independently of specific local situations. This concentration on education is not likely to be judged as misplaced. Employment opportunities in American society have shifted to occupations which require more and different kinds of education.

There are tensions generated by this first perspective, and this leads to the second perspective. Accompanying the movement of any large-scale industry into a rural area is a necessary cadre of management, supervisory personnel, and skilled craftsmen-people who are acutely aware of the import of the changed nature of prospective employment. Since the schools of many rural areas may not match the quality of those in other areas, a sense of impatience and relative deprivation is likely to develop. Measured resistance may confront efforts to improve the local educational enterprise from those people who are unaware of the kind of life for which the children must prepare. People who resist may not be sharing in the general prosperity, or for other reasons feel neglected, and they may find the means for expressing a latent resentment. This bulletin, a case study, seeks to detail facets of educational attitudes and values in just such a situation. 


\section{Introduction}

Most rural communities of the Northeast ${ }^{1}$ have become increasingly aware of the significance of new employment opportunities to industrial development in the region. Inclustrialization brings with it employment, income, and a chance to broaden and strengthen the local economy of the community. With economic derelopment comes accompanying problems of change and adjustment.

While it is conceded that the industrialization is beneficial through providing employment and income to local residents and to the inmigrants, relatively little research has been undertaken to delineate the influences accompanying industrialization on attitudes toward education and schools. This study is concerned with the attitudes of two groups-the native population and the in-migrants-as related to education.

The county in which this study was undertaken was selected because it had experienced a tremendous change in the last ten years. In 1956, a large integrated aluminum plant was put into operation by the Kaiser Aluminum and Chemical Corporation near Ravenswood, West Virginia. As a result of the establishment of this plant, there has been an influx of new workers and their families into a once distinctly rural area. Although the in-migrants may accept subordinate positions, they make an impact on the style of life which tends to change community patterns. The native population is confronted with realignments, constituting a shift from a distinctly rural to urban community.

Under these conditions, the natives of the rural community, characterized by traditional patterns of behavior, and the in-migrants, characterized by rational patterns, ${ }^{2}$ may become involved in a clash of values. The in-migrants may seek to further their values by becoming leaders in educational organizations and functions.

This study sets side by side the trio groups so that comparisons can be made. These efforts should be helpful to rural and urban planners, farm

1The study was undertaken in conjunction with Northeast Regional Project No. 47 "The Social and Economic Consequences of Changes in Employment Upon Selected Northeastern Communities."

${ }^{2}$ Charles P. Loomis and J. Alian Beegle, Rural Social Systems (New York: PrenticeHall Inc., 1950), p. 21. 
people, rural leaders, and others in understanding an area of conflict which is likely to occur in the industrialization of a rural area.

\section{2}

\section{Jackson County in Perspective}

In order to understand the effects of industrialization on educational attitudes, a "before and after" glance at the county is needed.

\section{Jackson County}

"Jackson county lies in the western part of the State on the Ohio river, which washes its... boundary for a distance of twentyfour miles. It is bounded on the north by Wood county; east by Wirt and Roane; south by Kanawha; southwest and west, by Putnam and Mason. At the time of its formation (1831) it was increased by an addition from Mason, so that the present area is 471.98 square miles ... The lowest depression in the county is 300 feet above sea level, and the highest point rises to a height of 600 feet." ${ }^{3}$

Prior to the year 1955, Jackson County was predominantly an agricultural county with only a small amount of its work force employed in manufacturing. With the coming of the Kaiser Aluminum and Chemical Corporation, the economy has become more evenly balanced between igriculture and industry.

In 1960, Jackson County had a population of 18,541. This tas a 21.2 per cent increase in population since 1950 and a net change of $3,242 .{ }^{4}$ There were 5.053 heads of households: 3,214 were rural, 881 were located in Ripley, and 958 in Ravenswood. The population per household was 3.66. The median age of residents in the county, according to the latest Census figures, is 26.4, 1.4 years lower than in 1950; 8.7 per cent of the population is over 65.5

H. H. Hardesty, Harlesty's Historical and Geographical Encyclopedia (Chicago anr] Toledo: H. I1. Hardest! and (o., 1883). p. 290, 291.

tCurrent Population Reports series 123, No. 7. Nov. 1962, p. 57.

U. S., Bureau of the Census, Eighteenth Census of the L'nited states: 1960. Popu-
lation, Table 27, p. 64. 
In 1960 there were 7,700 persons in the labor force in Jackson County, approximately 80 per cent of whom were males. About 42 per cent were engaged in manufacturing. The median income for families and unrelated individuals was $\$ 4,307$, and the per capita income was $\$ 2,348$. In 1950 over half-65.1 per cent-of the families had an income less than $\$ 2,500$, while in 1960 , only 10.3 per cent had an income less than $\$ 2,500$. In the period 1954-1957, total personal income increased to $\$ 55,168,000$. This was due to the construction boom at the plant. ${ }^{6}$

The total school enrollment for the county was 4,199 in 1960 ; this figure contains the age group from 5 to 34 years old. Thirty-one were in college; the remainder, 4,168 , were in the primary and secondary schools. The median number of years of schooling completed was the same for both males and females, 8.8. The primary and secondary school enrollment, at the present time, is 5,400; this figure represents a net increase of 1,232 since 1960 .

In 1950 , the county had 74 school buildings with a total of 142 classrooms. By 1960, the number of buildings decreased to 32 , but the number of classrooms increased to 175 , the result of construction of new buildings and the closing of many one-room schools.

\section{Comparison of Jackson and Roane Counties}

Prior to the coming of the industrial complex, the economy of the area was static. Only small increases were shown in the various economic indicators during the years 1950-1955. To better illustrate the effects of a 3,000-man employer, a comparison of Jackson County with Roane County is offered. Roane County was chosen because it was similar to Jackson County-both being agricultural counties-prior to the construction of the plant.

${ }^{6}$ Economic Review of Jackson County, 1950-1960. Prepared by the Area Development Department, Appalachian Power Company.

7 U. S. Bureau of the Census, Eighteenth Census of the United States:1960. General Social and Economic Characteristics, Table 83, p. 156. 
TABLE 1

Selected Comparisons of Jackson County and Roane County

\begin{tabular}{|c|c|c|c|c|c|c|}
\hline \multirow{2}{*}{ Selected Comparisons } & \multicolumn{3}{|c|}{ Jackson } & \multicolumn{3}{|c|}{ Roane } \\
\hline & 1950 & 1960 & $\begin{array}{c}\text { Per Cent } \\
\text { Change } \\
\end{array}$ & 1950 & 1960 & $\begin{array}{l}\text { Per Cent } \\
\text { Change }\end{array}$ \\
\hline Population & 15,299 & 18,541 & +21.2 & 18,408 & 15,720 & -14.6 \\
\hline $\begin{array}{l}\text { Total Assessed Valuation } \\
\text { Total Expenditures bs }\end{array}$ & $\$ 21,983$ & $\$ 54,582$ & +148.3 & $\$ 25,862$ & $\$ 28,288$ & +9.4 \\
\hline $\begin{array}{l}\text { County Government* } \\
\text { Total Amounts }\end{array}$ & 77.1 & 317.5 & +311.8 & 88.6 & 168.6 & +90.3 \\
\hline $\begin{array}{l}\text { Expended for Public } \\
\text { School Education* ... }\end{array}$ & 836 & 1.157 & +3 & 785 & 851 & +8.4 \\
\hline Personal Income* .. & 15.008 & 43,904 & +192.5 & 13.904 & 22,893 & $\begin{array}{r}+0.4 \\
+64.7\end{array}$ \\
\hline Per Capita Income & 1,096 & 2,348 & +114.2 & 822 & 1,444 & +75.7 \\
\hline Retail Sales* ....... & 6.705 & 13,543 & +102.0 & 6.578 & 9,979 & +51.7 \\
\hline
\end{tabular}

*In Thousands of Dollars.

Data Source: Leonard M. Sizer, County Study Data Book, Bulletin 464, West V'irginia University Agricultural Experiment Siation, 1961.

As shown in Table 1, Jackson County had an increase in population (21.2 per cent) from 1950-1960, while Roane had a decrease (-14.6 per cent) in the same period. This decrease was not unique to Roane County; many other agricultural counties in the United States were confronted with such a loss. The ability of a large industrial complex to attract in-migrants and stabilize the native population is illustrated by these data.

In 1960, the total assessed valuation of all property in Jackson County was $\$ 54,582,000$, an increase of 148.3 per cent from 1950. Roane County in 1960 had a total assessed valuation of property of $\$ 28,288,000$, representing an increase of 9.4 per cent from 1950. Jackson County's increase was 138.9 per cent greater than Roane's.

The total expenditures by county governments is also indicative of the great influence of a large firm. Jackson County liad an increase of 311.8 per cent; Roane County had only a 90.3 per cent increase.

\section{4}

\section{Problem, Procedure and Methodology}

The particular problems of this bulletin are drawn from a larger study that states: "The objective of this study is to determine the consequences of changes in employment upon the social organization of selected communities in the Northeast region. Each of the eight states (Maine, 
New Hampshire, Vermont, Rhode Island, New Jersey, Delaware, Pennsylvania, and West Virginia) participating in this objective is conducting field studies in ore or more communities. The communities werc selected on the basis of the following criteria: the degree of impact of changes in employment opportunities and sources; the importance of the specific situation for the state as a whole; the degree to which data from the individual communities can be generalized to the region."s

With the above criteria in mind, Jackson County was chosen for study. The movement of new workers and their families into a once rurai area, thus suddenly changing it, presents a complex development for study. The immediate concern of this study is limited to a consideration of the attitudes of the residents of the county toward education. The hypothesis under study is summarized below.

The impact is seen in the total amounts expended for public school education, although it is not as great. Jackson County had an increase of 38.4 per cent from 1950-1960 and Roane County had an increase of 8.4 per cent in the same period.

The impact on the economy of Jackson County can best be seen 11 total personal income, per capita income, and retail sales. These indicators increased 192.5 per cent, 114.2 per cent, and 102.0 per cent, respectively. Roane County, however, had increases of only 64.7 per cent, 75.7 per cent, and 51.7 per cent, respectively (Table 1).

The number of doctors, dentists, and registered nurses has increased in Jackson County and decreased in Roane. Recently, Jackson County completed a new general hospital.

The selected comparisons will illustrate the size of the impact of a large industrial complex upon a rural community. Jackson had a much the respondents' opinion of education and the schools in Jackson County. into the county after January 1, 1954. As shown in Table 244.2 per cent capita income, and retail sales than did Roane County.

\section{Hypothesis}

The establishment of the Kaiser Aluminum plant in Ravenswood, West Virginia, brought into the county a new population, including technical and managerial personnel.

The basic hypothesis of this study is that the in-migrants brought with them a set of educational values and norms which are different from those of the older, established population. The principal sub-hypothesis

sThis statement was taken from the Northeast Project Proposal, Number 47. 
is that a conflict of values resulted, and that the in-migrants have sought to implement their values through leadership in the local P.T.A.', through working for congenial nembers of the school board, and through working for school levies.

The basic hypothesis, that different educational values are held by the old and new residents, is to be tested by comparing the relevani attitucles which are clisclosed in a survey of a representative sample of households. The testing of the main sub-hypothesis includes data gathered in informal interviews with members of organizations and with townspeople knowledgeable about local current events, and also from information gathered in the field survey.

\section{Schedule}

The section of the schedule pertinent to this particular phase of the study consisted of two parts. The first part was basically concemed with the respondents' opinion of education and the schools in Jackson County.

The second part was concerned with obtaining information abour the respondents activities (participation) with regard to the schools.

A schedule was prepared for interviews with the head of the household, or the wife of the head.

\section{Construction of Attitude and Participation Scales}

An attitude can be defined as "an enduring organization of motivational, emotional, perceptual, and cognitive processes with respect to some aspect of the individual's world." Attitudes are influenced partly by the individual's value system and partly by his experiences.

Information about attitudes provicles clues to a pattern of response. A scaling technique was devised so as to obtain responses that would represent the range of attitudes. The qualitative differences were assigned quantitative values. The construction of scales makes possible a statistical analysis of the data. Such analysis will contribute to an understanding of the data and the results which may be stated in terms of statisticil tests of significance.

Because of time and resource limitations, only a small sample of the factors involved in ascertaining attitudes toward education could be measured. Since the sample included families in all stages of the family life cycle, some questions were not applicable to all; e.g., families who

9James Nielson, The Farm Families .. Their Allitudes, Goals and Goal Achievement. Bulletin 287, Michigan State I niversity Agricultural Experiment Station, 1962. 
had no children in school could not answer all questions concerning the schools. However, there is a comparison made, eliminating this group of respondents.

Attitude Toward Education - The construction of the attitude toward education scale was based on the response of each interviewee to questions dealing with his opinion of schooling. Eight questions were selected: (1) How much of a handicap is it to boys and girls of this county if they do not finish high school? (2) How much help to children are the things they learn in school today? (3) How would you feel if your child quit before graduating from high school? (4) Have you strongly encouraged your children to continue education beyond high school? (5) How much education would you like your child to have? (6) Would you take money out of your savings to send your child to school? (7) Would you be willing to see your son or daughter go into rlebt in order to go on in school? (8) Would you be willing to go into debt so that your children would be able to go to schooil?

The responses to the statements were weighted on a scale of 1 to 5 , from least favorable to most favorable. The values for each set of statements were summed to form the respondents' total score. A maximum score of forty and a minimum of eight could be attained. The total score of each respondent was then added and a mean score for the two groups was derived.

The responses offered for each item are not uniform, that is, each has a different set of responses but the weighting procedure is the same. In a few instances the weight of three represents a neutral position. For convenience in scoring, those respondents indicating blanks, don't know, and not applicable, etc., were given the value of three.

Attitude Toward the Schools and Teachers - The construction of this particular scale was made to determine the respondents' opinion of the schools and teachers of Jackson County. The questions used as the basis for this scale are as follows: (I) Do you think the teachers are paid too much, etc? (2) Would you say that most of the teachers in this county, as compared with elsewhere, are: much better, etc? (3) At the present time, how much need is there for improving the schools? (4) How do the schools in this county compare with schools in neighboring counties in the State? (5) How do the schools in this county compare with schools elsewhere in the United States? (6) Would you say that you are completely satisfied with the schools? (7) In your opinion, are the education standards in this county: very high, etc?

As above, the responses were weighted 1 to 5 , but in this case indicated satisfaction or dissatisfaction with the schools and teachers. The 
procedure is the same as above for arriving at the final mean score. However. in this scale, a maximum of 35 points indicates a high degree of dissatisfaction and a minimum of 7 points indicates a high degree of satisfaction.

Participation in School dctivities - This scale measures the respondents' activities with regard to the schools. The questions asked are is follows: (1) How often did you attend P.T.A. meetings? (2) Were you ever an officer of the P.T.A.? (3) Have you worked for the election of certain school board members? (4) How many times have you visited a meeting of the board? (5) Have you worked for school levies? (6) Did you rote in levy elections? (7) Do you discuss school programs with teachers or principals: (8) Do you cliscuss school programs with the superintendent? (9) Have you discussed the quality of schools with friends and neighbors?

The responses to these statements indicating degrees of participation were weighed from 1 to 3 , except in one instance the weighing was from I to 2 (item 2). The procedure for arriving at the mean scores for the two groups is the same as the one discussed above. But, in this case, a maximum of 26 points indicates a high degree of participation and a minimum of 9 points a low degree of participation.

\section{Analysis Pattern}

Systematically, each of the hypotheses for samples of both the total population and parents of school pupils was tested to find the likelihooci that the differences could have occurred by chance. ${ }^{10}$

\section{Collection of Data}

Data was collected from a representative sample of households in Jackson County-a j per cent probability sample in rural Jackson County, a 10 per cen area probability sample of Ripley and a 10 per cent list-cluster sample of Rarenswood. Ripley and Ravenswood sam. pling rates were larger to obtain a larger number than the rural sampling rate would allow. The number of returns in the rural area and Ripley fell short of expectation; Ravenswood's number was within the expected range. No adjustments in the statistical analysis were made for the varying sample rates, in as much as the major emphasis for comparison was with sub-samples, migrant and non-migrant.

1"Technically, a mull hypothesis of no difference was used. together with sumdents " $t$ " and alo by the analrsis of covariance. 
Two hundred eighty-four household heads or their wives were successfully interviewed by three trained interviewers during June and July, 1964 , with the use of a schecluled questionnaire.

\section{Characteristics of the Sample}

A discussion of certain demographic factors is needed to determine the similarities and dissimilarities of the two populations. These characteristics are influencing factors that may bear on the hypothesis.

\section{Residence}

The in-migrant population was defined as those who had moved into the county after January 1, 1954. As shown in Table 2, 44.2 per cent of the in-migrants had lived in the county for less than four years, and 55.8 per cent for four or more years.

This indicates that a large proportion of the in-migrants are rela. tively recent arrivals and it also suggests that the proportion met the initial labor demands of Kaiser Aluminum.

The largest proportion of in-migrants, 33.6 per cent, were from noncontiguous counties of West Virginia and the next largest, 27.9 per cent, were from contiguous counties of West Virginia. This indicates

TABLE 2

Length of Residence of In-migrant and Native Sample, Jackson County, West Virginia, 1965

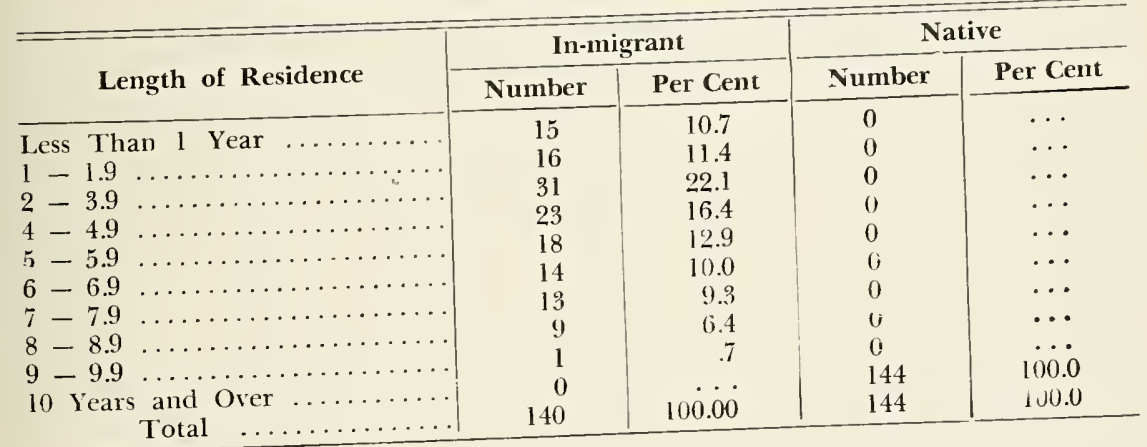




\section{Place of Previous Residence of In-migrants, Jackson County,} West Virginia, 1965

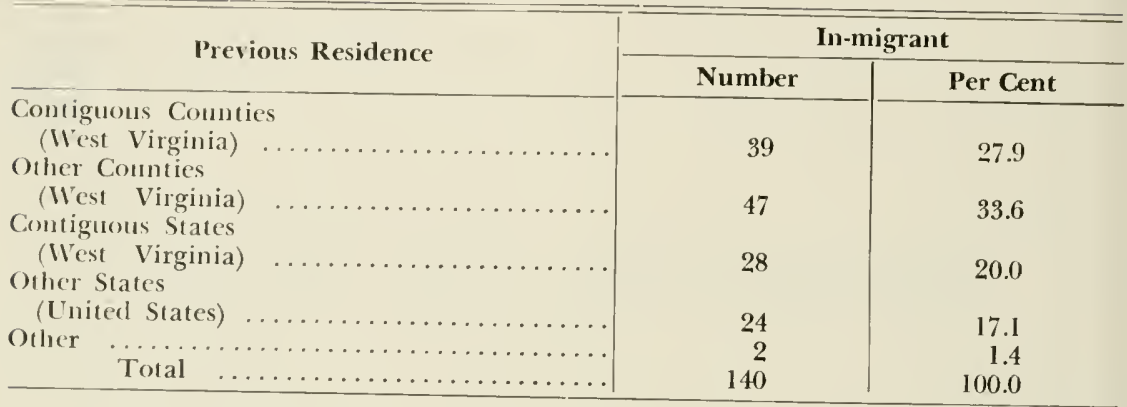

that the majority of the in-migrants, 61.5 per cent, that migrated into Jackson County were West Virginia residents. The remainder were from contiguous and noncontiguous states and other areas, 20.0 per cent, 17.1 per cent, 1.4 per cent, respectively (Table 3).

\section{Age and Sex}

The largest proportion of in-migrants, 40.7 per cent, are in the age category 30-39; the next largest $40-49,25.7$ per cent. The majority 66.4 per cent, are within the age grouping $30-49$ (Table 4).

There were two categories of the native sample having the largest proportion, 40-49 and 50-59, both with 20.1 per cent. The next largest grouping was 60-69 years, with 18.8 per cent. The majority of the native population, 59.0 per cent, are, then, between the ages 40 and 69 years.

This suggests that the in-migrant population is relatively younger than the native population.

\section{TABLE 4}

\section{Age Distribution of In-migrant and Native Sample, Jackson County, West Virginio, 1965}

\begin{tabular}{|c|c|c|c|c|c|}
\hline & \multirow{2}{*}{ Age } & \multicolumn{2}{|c|}{ In-migrant } & \multicolumn{2}{|c|}{ Native } \\
\hline & & Number & Per Cent & Number & Per Cent \\
\hline $\begin{array}{l}20-29 \\
30-39 \\
40-49 \\
50-59 \\
60-60 \\
70-79 \\
80-89\end{array}$ & 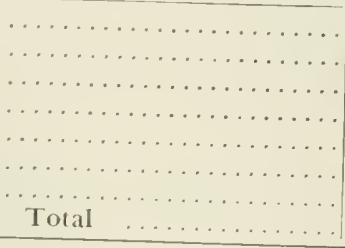 & $\begin{array}{r}27 \\
57 \\
36 \\
12 \\
6 \\
2 \\
0 \\
140\end{array}$ & $\begin{array}{r}19.3 \\
40.7 \\
25.7 \\
8.6 \\
4.3 \\
1.4 \\
0.0 \\
100.0 \\
\end{array}$ & $\begin{array}{r}16 \\
13 \\
29 \\
29 \\
27 \\
23 \\
7 \\
144\end{array}$ & $\begin{array}{r}11.1 \\
9.0 \\
20.1 \\
20.1 \\
18.8 \\
15.9 \\
4.9 \\
100.0 \\
\end{array}$ \\
\hline
\end{tabular}


TABLE 5

Sex of Head of Household of In-migrant and Native Sample, Jackson County, West Virginia, 1965

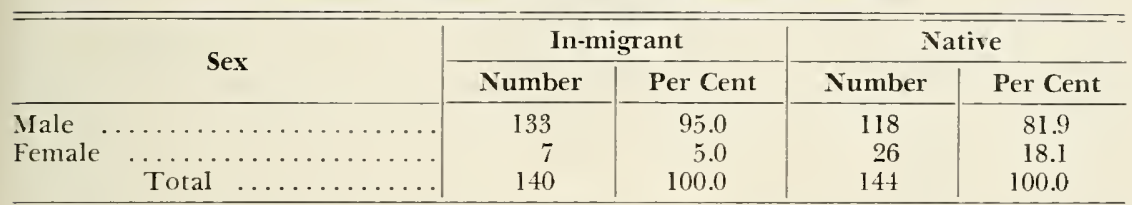

In keeping with expectations based upon the age distribution of the two populations, the in-migrants had a larger per cent with male household heads, 95.0 per cent and 81.9 per cent, respectively (Table 5).

\section{Education and Income}

The in-migrants of this study have had more education proportionately than the native population. Forty per cent of the in-migrants have graduated from high school, while 17.4 per cent of native population have graduated from high school. Of the in-migrants, 66.3 per cent have had 12 or more years of education, while 32.8 per cent of the natives have had 12 or more years. The median number of years completed for the in-migrants and natives is 12.4 and 8.7 (Table 6).

The largest proportion. 35.0 per cent, of the in-migrants have incomes between $\$ 6,000$ and $\$ \$, 000$ : the next largest proportion, 20.7 per cent, have incomes between $\$ 8,000$ and $\$ 10,000$. The majority (proportionately), 55.7 per cent, have incomes between $\$ 6,000$ and $\$ 10,000$. The median income for the in-migrants is $\$ 6,612$.

\section{TABLE 6}

Highest Year of School Completed of In-migrant and Native Sample, Jackson County, West Virginia, 1965

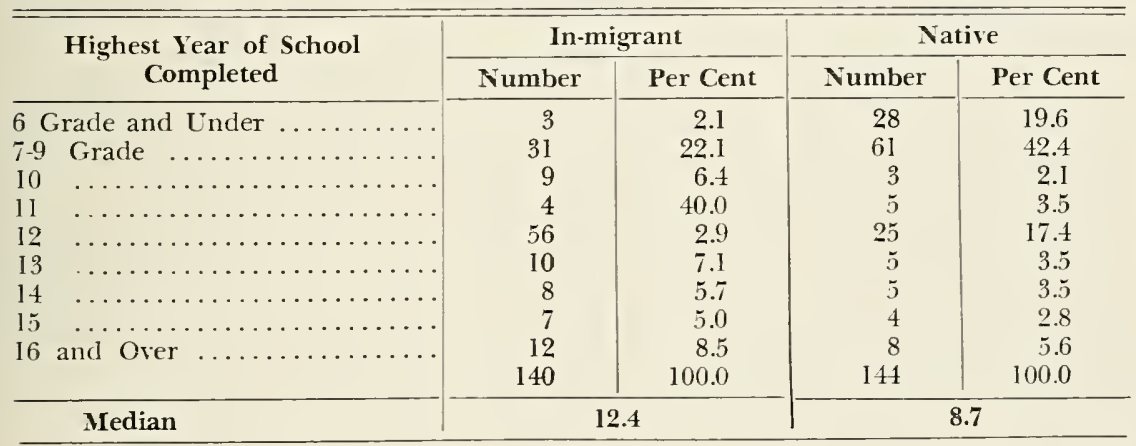


The first set of three bars represents the average EPG in the fecal samples taken before treatment and establishes the low level of parasite infection which did not increase during the trials. Although the level of infection did not permit a really critical evaluation of the three treatments, it can be seen that thiabendazole was consistently the most effective in reducing the number of eggs per gram of feces.

Athough Trichuris ovis and Strongyloides papillosus are parasites found in sheep, they are not believed to ordinarily influence lamb performance in the area represented in these trials. However, this might change under certain conditions and thus the effectiveness of the three treatments in the control of these two parasites was determined. From the results recorded in Figure 2 it can be seen that none of the treatments appeared to be effective against Trichuris ovis. However, in Trial 4 of the 1960 grazing season phenothiazine appeared to be effective against T'richuris ovis. On the other hand, Strongyloides papillosus was effectively controlled by thiabendazole, as shown in Figure 3, and this is in agreement with the results of trial 4, Table 4. In both trials phenothiazine was ineffective in controlling Strongyloides papillosus. Continuous Use of Thiabendazole in a Commercial Ewe Flock

The regular use of an anthelmintic over a long period of time may permit the development of parasite strains tolerant to the material.

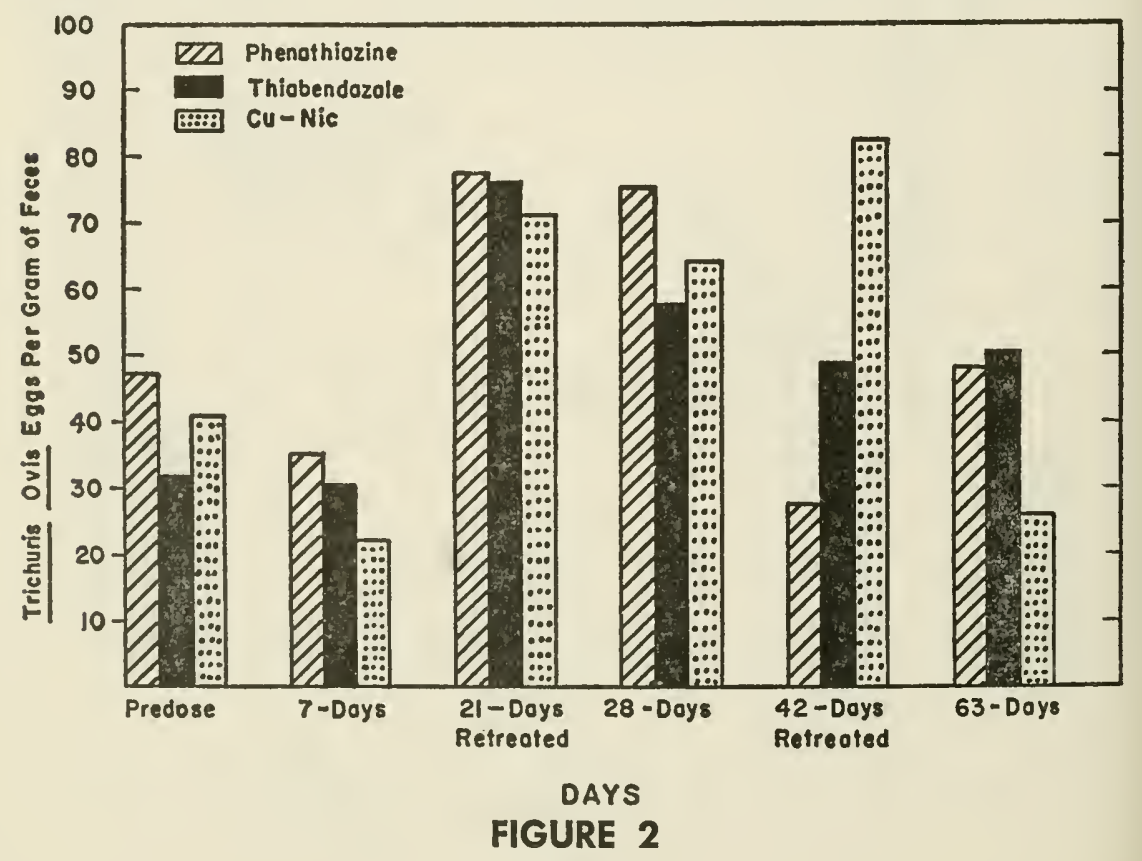


The observations of the Kentucky workers mentioned earlier suggest that this was the case with phenothiazine and the major sheep parasite, Haemonchus contortus.

It was with this in mind that one of the commercial ewe flocks involved in the initial 1960 trials was continued on thiabendazole. This flock of 125 cross-bred white-face ewes is managed to lamb during the early fall. Pasture rotation is practiced, with availability of feed determining change of pastures.

Beginning in August 1960, a systematic thiabendazole treatment program was begun. Every 21 days all ewes received one ounce of a commercial preparation which provided two grams of thiabendazole. On the basis of ewe weights at that time, this dose was calculated to provide $50 \mathrm{mg}$ of thiabendazole per kilogram of body weight. Although a gradual increase in body weight was apparent as the trial progressed, no adjustment in treatment level was made until January 1964. As a result of the gradual increase in body weight $(90$ to $140 \mathrm{lb}$ ), the treatment level had fallen from about $50 \mathrm{mg}$ per kilogram of body weight to about $30 \mathrm{mg}$. Accordingly, the quantity of material was increased to 1.5 oz or the equivalent of $3 \mathrm{gr}$ of thiabendazole per ewe $(44 \mathrm{mg} / \mathrm{kg}$ of body weight). At the same time, the treatment schedule was changed

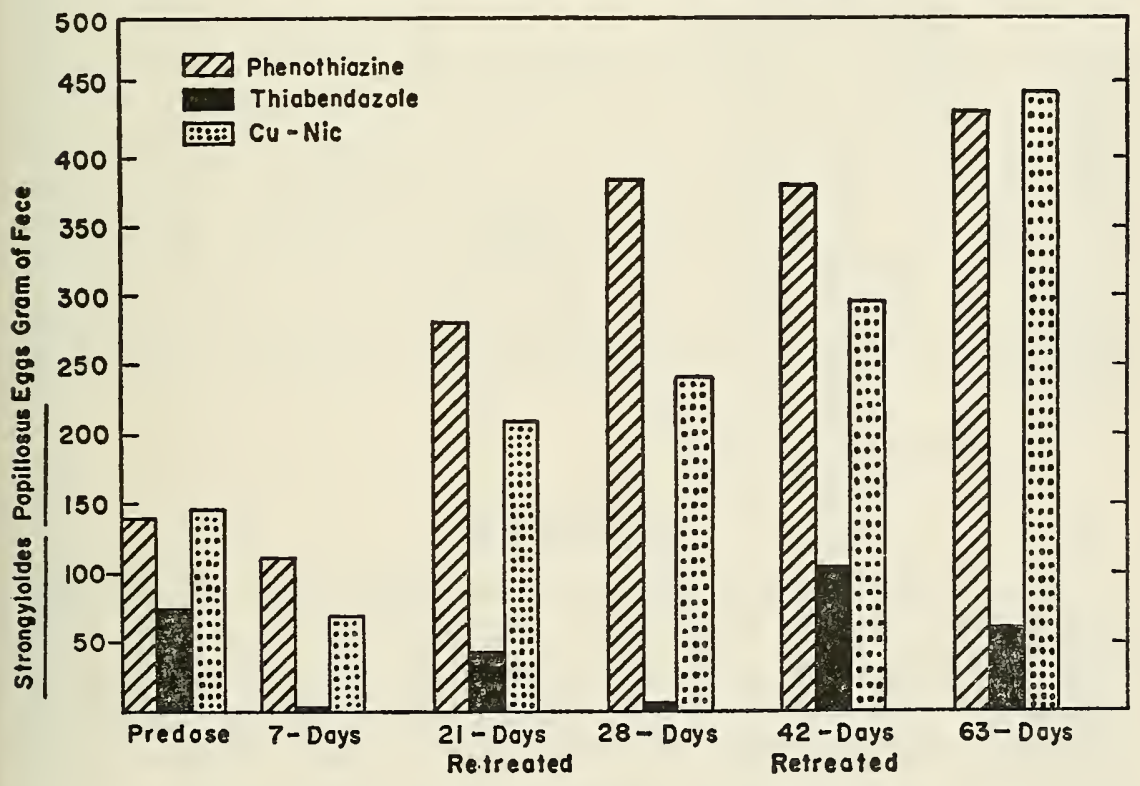

DAYS

FIGURE 3 


\section{Summary}

The location of a large industrial plant in a rural area will necessitate the influx of new residents. This occurred in Jackson County. A large proportion of the newcomers are relatively recent migrams, but a larger proportion met the initial labor demands of Kaiser Aluminum and the need for expanded services in the county.

The majority of in-migrants were from West Virginia. The largest proportion came from noncontiguous counties.

The in-migrant population is relatively younger than the native population.

The in-migrants have had more education and have larger incomes than do the natives. The median level of education for the in-migrants is 12.4 years, and for the natives, 8.7 . The median income for the natives is $\$ 3,400$ and for the in-migrants it is $\$ 6,612$.

The in-migrants and natives are similar in that the largest proportions of both consist of households with married couples with children in school: However, the in-migrants tend to have larger families.

\section{6}

\section{Attitudes of the Total Sample \\ Toward Education and the Schools}

\section{Attitudes Toward Education}

In this and the two following chapters the hypothesis to be tested is that the in-migrants brought with them a set of educational values and norms which are different from those of the older established population. This hypothesis is to be supported by comparing the attitudes of the in-migrants and natives toward education and the schools.

The individuals interviewed in this study indicated that they strongly supported the typically American faith in the value of formal education. However, clifferences exist between the in-migrants and the natives. The newcomers seem to have more favorable attitudes toward education than do the old residents.

In each of the items in Table 11 the in-migrants have a larger per cent in the responses which are indicative of favorable attitudes toward elucation. Of the in-migrants, 92.2 per cent believe the things children 


\section{TABLE 11}

\section{Educational Attitudes of the Total Sample, Jackson County, West Virginia, 1965}

\begin{tabular}{|c|c|c|c|c|}
\hline \multirow{2}{*}{ Educational Attitudes } & \multicolumn{2}{|c|}{$\begin{array}{l}\text { In-migrant } \\
\quad \mathrm{N}=140\end{array}$} & \multicolumn{2}{|c|}{$\begin{array}{l}\text { Native } \\
\mathrm{N}=144\end{array}$} \\
\hline & $\begin{array}{l}\text { Number } \\
\text { Agreeing }\end{array}$ & Per Cent & $\begin{array}{c}\text { Number } \\
\text { Agreeing }\end{array}$ & Per Cent \\
\hline $\begin{array}{l}\text { Not Finishing High School } \\
\text { is a Great Handicap. }\end{array}$ & 123 & 87.8 & 122 & 84.7 \\
\hline $\begin{array}{l}\text { Things Children Learn in } \\
\text { School are a Great Help }\end{array}$ & 129 & 92.2 & 117 & 81.3 \\
\hline Very Disappointed if Child & & & & \\
\hline Quit Before Graduating & 135 & 96.4 & 129 & 89.6 \\
\hline $\begin{array}{l}\text { Encouraged Children to Continue } \\
\text { Education Beyond High School }\end{array}$ & 106 & 75.8 & 103 & 71.5 \\
\hline $\begin{array}{l}\text { Would Like Children to Have } \\
\text { College Education .......... }\end{array}$ & 128 & 91.4 & 112 & 77.7 \\
\hline $\begin{array}{l}\text { Wonld Take Money out of Savings } \\
\text { to Send Children to School ... }\end{array}$ & 134 & 95.7 & 115 & 79.9 \\
\hline $\begin{array}{l}\text { Would be Willing to let Children go into } \\
\text { Debt for More Education ............ }\end{array}$ & 110 & 78.6 & 99 & 68.8 \\
\hline Would be Willing to go Into Debt Myself & 125 & 89.3 & 108 & 75.0 \\
\hline Mean Score* & \multicolumn{2}{|c|}{$\begin{array}{l}\text { In-migrant } \\
36.1\end{array}$} & \multicolumn{2}{|c|}{$\begin{array}{l}\text { Native } \\
33.6\end{array}$} \\
\hline
\end{tabular}

* The value of the difference of the two percentages for samples of this size could happen only by chance less than one time in a hundred.

learn in school are a great help, while 81.3 per cent of the natives believe the same. A large per cent, 91.4, of the newcomers would like their children to have a college education contrasted to 77.7 per cent of the old residents. Of the in-migrants, 95.7 per cent would use money from their savings ard 75.0 per cent would be willing to go into debt to provide for additional education. Differences also exist in the remainder of questions asked, but are not as great.

The next step in the analysis of the clata was to test the null bypothesis of no difference between the attitude toward education mean scores of the in-migrants and natives. The mean scores of the inmigrants and natives, 36.1 and 39.6 respectively, were found to be significant. Therefore, the in-migrants have more favorable attitudes toward formal education than does the indigenous population.

\section{Evaluation of Teachers}

The respondents were asked to evaluate the teachers in three ways: whether or not the teachers were doing a good job; whether the teachers were paid too much or too little; whether the teachers were as good or better than teachers elsewhere. 
Slightly fewer than half of the respondents, both in-migrants and natives, said the teachers were doing a good job; slightly over a third said they were doing a fair job. The two groups differed concerning the pay of teachers: 67.8 per cent of the in-migrants indicated that the teachers were paid too little and 38.9 per cent of the natives indicated the same. Exactly half of the newcomers indicated the teachers were much better, or about the same, as elsewhere, while over half of the natives said the same (Table 12).

\section{TABLE 12}

\section{Evaluations of Teachers by the Total Sample, Jackson County, West Virginia, 1965}

\begin{tabular}{|c|c|c|c|c|}
\hline \multirow[t]{2}{*}{ Evaluation } & \multicolumn{2}{|c|}{$\begin{array}{c}\text { In-migrant } \\
N=140\end{array}$} & \multicolumn{2}{|c|}{$\begin{array}{l}\text { Native } \\
N=144\end{array}$} \\
\hline & Number & Per Cent & Number & Per Cent \\
\hline $\begin{array}{l}\text { What Kind of job do you Feel } \\
\text { the Teachers are Doing? } \\
\text { Good }\end{array}$ & & & & \\
\hline 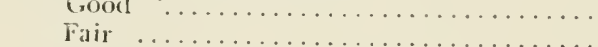 & 61 & 43.6 & 63 & 43.7 \\
\hline Poor & 51 & 36.4 & 48 & 33.3 \\
\hline Don't Know & 11 & 7.9 & 10 & 6.9 \\
\hline $\begin{array}{l}\text { Do you Think the Teachers } \\
\text { are paikl: }\end{array}$ & 15 & 10.7 & 18 & 12.5 \\
\hline Too Nuch or Right Amount & 19 & 13.6 & 49 & 34.1 \\
\hline Ton Little or Definitely Underpaid & 95 & 67.8 & 56 & 38.9 \\
\hline The Teachers of This Comnty as & 25 & 17.9 & 35 & 24.3 \\
\hline $\begin{array}{l}\text { Compared with Elsewhere are: } \\
\text { Much Better or About the Same }\end{array}$ & 70 & 50.0 & 80 & 55.6 \\
\hline Not as Good or Definitely Worse. & 40 & 28.5 & 21 & 14.6 \\
\hline 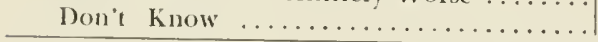 & 28 & 20.0 & 38 & 26.4 \\
\hline
\end{tabular}

\section{Evaluation of the Schools}

The respondents were asked a number of questions concerning their evaluation of the schools. Of the in-migrants, 87.9 per cent indicated that there was a great, or moderate, need for improving the schools, while only 67.4 per cent of the natives said the same. Of the natives, 47.2 per cent said the schools in Jackson County were much better, or about the same, as schools in neighboring counties of the State, and 35.0 per cent of the in-migrants indicated the same. In comparing the schools in the county with others in the United States, 52.1 per cent of the in-migrants and 27.8 per cent of the natives said they were not as good. When asked if they were satisfied or dissatisfied with the schools. 58.6 per cent of the newcomers and 29.1 per cent of the old residents indicated dissatisfaction. That the educational 


\section{Evaluation of Schools by the Total Sample, Jackson County, West Virginia, 1965}

\begin{tabular}{|c|c|c|c|c|}
\hline \multirow[t]{2}{*}{ Evaluation } & \multicolumn{2}{|c|}{$\begin{array}{c}\text { In-migrant } \\
N=140\end{array}$} & \multicolumn{2}{|c|}{$\begin{array}{l}\text { Native } \\
\mathrm{N}=144\end{array}$} \\
\hline & Number & Per Cent & Number & Per Cent \\
\hline Need for Improving the Schools: & & & & \\
\hline Great or Moderate...$\ldots$. & 123 & 87.9 & 97 & 67.4 \\
\hline Little or None $\ldots \ldots \ldots \ldots$ & 7 & 5.0 & 10 & 7.0 \\
\hline $\begin{array}{l}\text { Don't Know ............................. } \\
\text { Comparison of Schools in Jackson County }\end{array}$ & 8 & 5.7 & 32 & 22.2 \\
\hline \multirow{2}{*}{\multicolumn{5}{|c|}{$\begin{array}{l}\text { Comparison of Schools in Jackson County } \\
\text { with Schools in Neighboring Counties } \\
\text { in the State: }\end{array}$}} \\
\hline & & & & \\
\hline Much Better or About the Same .... & 49 & 35.0 & 68 & 47.2 \\
\hline $\begin{array}{l}\text { Not as Good or Definitely Worse } \ldots \ldots \\
\text { Don't Know }\end{array}$ & 50 & 35.7 & 27 & 18.8 \\
\hline $\begin{array}{l}\text { Don't Know ................................ } \\
\text { Comparison of Schools in Jackson County }\end{array}$ & 39 & 27.9 & 44 & 30.6 \\
\hline $\begin{array}{l}\text { with Elsewhere in the United States: } \\
\text { Much Better or About the Same .... }\end{array}$ & $\begin{array}{l}\text { Comparison of Schools in Jackson County } \\
\text { with Elsewhere in the United Sta+es: }\end{array}$ & 15.0 & 24 & \\
\hline Not as Good or Definitely Worse .. & 73 & 52.1 & 40 & $\begin{array}{l}16.7 \\
27.8\end{array}$ \\
\hline 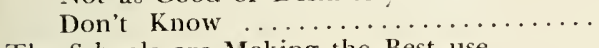 & 44 & 31.4 & 75 & $\begin{array}{l}27.8 \\
52.1\end{array}$ \\
\hline \multirow{2}{*}{\multicolumn{5}{|c|}{$\begin{array}{l}\text { The Schools are Making the Best use } \\
\text { of Money Available: }\end{array}$}} \\
\hline & & & & \\
\hline & 59 & 42.2 & 53 & 36.8 \\
\hline $\begin{array}{l}\text { Strongly Disagree or Disagree } \ldots \ldots \ldots \ldots \\
\text { Don't Know } \ldots \ldots \ldots \ldots \ldots \ldots \ldots \ldots \ldots\end{array}$ & $\begin{array}{l}43 \\
36\end{array}$ & 30.7 & 41 & 28.5 \\
\hline \multirow{2}{*}{\multicolumn{5}{|c|}{$\begin{array}{l}\text { Would You Say that You are: } \\
\text { Completely or Somewhat Satisfied with }\end{array}$}} \\
\hline & & & & \\
\hline $\begin{array}{l}\text { the Schools ..................... } \\
\text { Definitely or Somewhat Dissatisfied }\end{array}$ & 45 & 32.2 & 76 & 52.8 \\
\hline $\begin{array}{l}\text { Definitely or Somewhat Dissatisfied } \\
\text { Don't know' } \ldots \ldots \ldots \ldots \ldots \ldots \ldots \ldots\end{array}$ & 82 & 58.6 & 42 & 29.1 \\
\hline $\begin{array}{l}\text { Don't know } \ldots \ldots \ldots \ldots \ldots \ldots \\
\text { Education Standards of the }\end{array}$ & 11 & 7.9 & 21 & 14.6 \\
\hline \multicolumn{5}{|l|}{ Education Standards of the } \\
\hline $\begin{array}{c}\text { County are: } \\
\text { High } \quad \ldots\end{array}$ & 12 & 8.6 & 21 & 14.6 \\
\hline Average & 72 & 51.4 & 71 & 49.3 \\
\hline Low $\ldots . .$. & 35 & 25.0 & 15 & 10.4 \\
\hline Don't know & 19 & 13.6 & 33 & 22.9 \\
\hline Mean Score* & $\begin{array}{r}\text { In-mi } \\
2\end{array}$ & grant & & $\begin{array}{l}\text { tive } \\
1.1\end{array}$ \\
\hline
\end{tabular}

*The value of the difference of the two percentages for samples of this size could happen only by chance less than one time in a hundred.

standards in the county were low or average was indicated by 59.3 per cent of the natives and 76.4 per cent of the new residents (Table 13).

In testing the null hypothesis of no difference between the inmigrants' and natives' attitudes toward the schools and teachers mean scores, the null hypothesis was rejected. The scores of the in-migrants and natives, 24.1 and 21.1 respectively, were significantly different at the .01 level of significance. This difference indicates that the in-migrants are more dissatisfied with the schools and teachers than are the natives. 
TABLE 14

\section{Rating of School Provisions by the Total Sample, Jackson County, West Virginia, 1965}

\begin{tabular}{|c|c|c|c|c|}
\hline \multirow[t]{2}{*}{ Rating of Provisions } & \multicolumn{2}{|c|}{$\begin{array}{c}\text { In-migrant } \\
\mathrm{N}=140\end{array}$} & \multicolumn{2}{|c|}{$\begin{array}{l}\text { Native } \\
N=144\end{array}$} \\
\hline & Number & Per Cent & Number & Per Cent \\
\hline \multicolumn{5}{|l|}{ Transportation } \\
\hline Good $\ldots \ldots \ldots \ldots$ & 57 & 40.7 & 59 & 41.0 \\
\hline Fair $\ldots \ldots \ldots \ldots \ldots \ldots$ & 34 & 24.3 & 37 & 25.7 \\
\hline Poor $\ldots \ldots \ldots \ldots \ldots \ldots$ & 15 & 10.7 & 25 & 17.4 \\
\hline 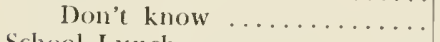 & 32 & 22.9 & 19 & 13.2 \\
\hline \multicolumn{5}{|l|}{ Scheol Lunch } \\
\hline Good $\ldots$ & 66 & 47.2 & 74 & 51.4 \\
\hline Fair $\ldots \ldots \ldots \ldots \ldots \ldots$ & 35 & 25.0 & 23 & 16.0 \\
\hline Poor $\ldots \ldots \ldots \ldots \ldots \ldots$ & 15 & 10.7 & 9 & 6.3 \\
\hline $\begin{array}{r}\text { Don't know } \ldots \ldots \ldots \ldots \ldots \\
\text { Buildinos }\end{array}$ & 22 & 15.7 & 33 & 22.9 \\
\hline \multicolumn{5}{|l|}{ Buildlings } \\
\hline $\begin{array}{l}\text { Good } \ldots \ldots \ldots \ldots \\
\text { Fair } \ldots \ldots \ldots \ldots \ldots\end{array}$ & 52 & $\begin{array}{l}37.1 \\
37.1\end{array}$ & $\begin{array}{l}79 \\
35\end{array}$ & $\begin{array}{r}54.8 \\
5.8\end{array}$ \\
\hline $\begin{array}{l}\text { Fair } \quad \ldots \ldots \ldots \ldots \ldots \ldots \ldots \\
\text { Poor } \quad \ldots \ldots \ldots \ldots \ldots\end{array}$ & $\begin{array}{l}52 \\
20\end{array}$ & 14.3 & $\begin{array}{r}35 \\
7\end{array}$ & $\begin{array}{r}24.3 \\
4.9\end{array}$ \\
\hline Doust know $\ldots \ldots \ldots \ldots \ldots \ldots$ & 14 & 10.0 & 19 & $\begin{array}{r}4.9 \\
13.2\end{array}$ \\
\hline \multicolumn{5}{|l|}{ Range of Subjects } \\
\hline Good $\ldots \ldots \ldots \ldots \ldots \ldots$ & 38 & 27.1 & 45 & 31.3 \\
\hline Fair $\ldots \ldots \ldots \ldots \ldots \ldots$ & 35 & 25.0 & 31 & 21.5 \\
\hline Poor $\ldots \ldots \ldots \ldots \ldots \ldots$ & 30 & 21.4 & 14 & 9.7 \\
\hline Don't know $\ldots \ldots \ldots \ldots \ldots$ & 34 & 24.3 & 50 & 34.7 \\
\hline \multicolumn{5}{|l|}{ Facilities } \\
\hline Good $\ldots \ldots \ldots \ldots \ldots \ldots$ & 37 & 26.4 & 46 & 32.0 \\
\hline Fair $\ldots \ldots \ldots \ldots \ldots \ldots$ & 40 & 28.6 & 34 & 23.6 \\
\hline Poor $\ldots \ldots \ldots \ldots \ldots \ldots$ & 31 & 22.3 & 18 & 12.5 \\
\hline $\begin{array}{l}\text { Don't know } \ldots \ldots \ldots \ldots \ldots \\
\text { Recreation }\end{array}$ & 30 & 21.4 & 42 & 29.2 \\
\hline \multicolumn{4}{|l|}{ Recreation } & \\
\hline $\begin{array}{l}\text { Good } \ldots \ldots \\
\text { Fair } \ldots \ldots \ldots\end{array}$ & $\begin{array}{l}+3 \\
44\end{array}$ & $\begin{array}{l}30.7 \\
31.4\end{array}$ & 55 & 38.2 \\
\hline 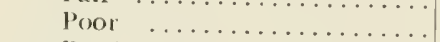 & 29 & $\begin{array}{l}31.4 \\
15.7\end{array}$ & 27 & 18.8 \\
\hline Don't know ............. & 29 & $\begin{array}{l}15.7 \\
20.7\end{array}$ & 17 & $\begin{array}{l}11.8 \\
98.5\end{array}$ \\
\hline \multicolumn{5}{|l|}{ Vocational Education } \\
\hline Good $\ldots \ldots \ldots \ldots \ldots \ldots$ & 28 & 20.0 & 47 & 32.7 \\
\hline Fair $\ldots \ldots \ldots \ldots \ldots \ldots \ldots$ & 21 & 15.0 & 19 & 13.2 \\
\hline Poor $\ldots \ldots \ldots \ldots \ldots \ldots$ & 26 & 18.6 & 14 & 9.7 \\
\hline Don't know ............ & 63 & 45.0 & 59 & 41.0 \\
\hline
\end{tabular}

\section{Ratings of Provisions}

The respondents were asked to evaluate school provisions in Jackson County. The ratings ranged from excellent to poor. To condense the data, the ratings of excellent and good were combined. The newcomers were expecterl to rate the provisions lower than the old residents. This held true in most cases.

When the two groups were asked to rate school bus transportation and the school lunch problem, they responded similarly. However, the old residents rated the transportation system lower (fair to poor) 
than did the new residents, 43.1 per cent and 35.0 per cent, respectively. The in-migrants rated the school lunch program a little lower than dis the natives, 35.7 per cent and 22.3 per cent, respectively. Possibly the natives give transportation a lower rating because they have greater need for buses.

When asked to rate the buildings, over half of the natives, but less than half of the in-migrants, rated them as good. Almost half of the newcomers, 46.4 per cent, and a third of the old residents, 31.2 per cent were dissatisfied with the range of subjects (ratings from fair to poor). Half of the in-migrants, 50.9 per cent, and 36.1 per cent of the natives rated the facilites in the schools from fair to poor. Over four-tenths of the in-migrants and less than three-tenths of the natives rated recreation from fair to poor. Nearly half of both groups indicated "don't know," when asked to rate rocational education. However, the in-migrants had a larger per cent indicating a rating of fair to poor (Table 14).

These clata point up, to a degrce, the dissatisfaction of the new: population with the existing school situation.

\section{Summary}

Available evidence thus far indicates that the in-migrants brought with them a set of educational values and norms that are different from those of the older established population. The in-migrants had a proportionately larger number giving responses which were indicative of favorable attitudes roward education. The attitude toward education mean scores of the in-migrants and natives, 36.1 and 33.6, respectively, was found to be significantly different.

The in-migrants were more clissatisfied with the teachers and the schools. The difference in the in-migrants' and natives' attitude toward the teachers and schools mean scores, 24.1 and 21.1, respectively, was found to be highly significant.

In most instances, the in-migrants rated the school provisions lower than did the natives. For the rating of transportation and the school lunch program, the in-migrants and natives were in agreement. 


\section{Attitudes of Parents of School Pupils Toward Education and the Schools}

In order to make the analy sis more precise, those respondents who indicated that they had no children in school were eliminated from consideration in this section. This procedure is followed because a number of the answers to questions clepended on whether the family hacl children in school. The group referred to in this section as the parent group. contain both in-migrants and natives as in the total sample.

\section{Attitudes Toward Education}

The parent sample was also asked questions that would provide information as to their attitucle about formal elucation. In the parent group, as in the total sample, the in-migrants had more favorable attitudes toward formal education than did the indigenous population. Howerer, when asked if they encouraged children to continue their edlucation beyond high school, the natives ranked higher than did the in-migrants, 94.5 per rent and 81.9 per cent, respectively. Of the new residents, 91.4 per cent indicated that the things children learn in school are a great help, contrasted to 77.6 per cent of the natives. When asked if they would like their children to have a college education, over nine-tenths of the in-migrants and orer seren-tenths of the natives answered this question affirmatively. Of the natives, 89.7 per cent, and of the in-migrants, 99.0 per cent, would be willing to withdraw money from their savings to send their children to school; 98.6 per cent of the in-migrants and 87.9 per cent of the natives would be willing to go into (lebt (Table 15).

The null hypothesis of no difference between the mean scores wat, again rejected. The difference between the scores of the in-migrants and natives, 36.7 and 34.9 respectively, was found to be significant at the .01 level of significance. Although the respondents with no children in xhool were eliminated from this analysin, the difference remained. The in-migrants have more favorable attitudes about education than do the natives. 


\section{TABLE 15}

Educational Attitudes of Parents of School Pupils, Jackson County, West Virginia, 1965

\begin{tabular}{|c|c|c|c|c|}
\hline \multirow{2}{*}{ Educational Attitudes } & \multicolumn{2}{|c|}{$\begin{array}{c}\text { In-migrant } \\
\mathbf{N}=94\end{array}$} & \multicolumn{2}{|c|}{$\begin{array}{l}\text { Native } \\
\mathrm{N}=58\end{array}$} \\
\hline & $\begin{array}{l}\text { Number } \\
\text { Agreeing } \\
\end{array}$ & Per Cent & $\begin{array}{l}\text { Number } \\
\text { Agreeing }\end{array}$ & Per Cent \\
\hline $\begin{array}{l}\text { Not Finishing High School is a } \\
\text { Great Handicap ................... }\end{array}$ & 85 & 90.4 & 49 & 84.4 \\
\hline 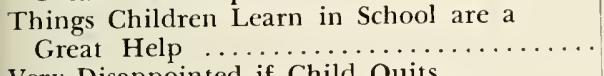 & 86 & 91.4 & 45 & 77.6 \\
\hline 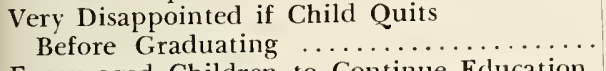 & 93 & 98.9 & 55 & 94.8 \\
\hline $\begin{array}{c}\text { Encouraged Children to Continue Education } \\
\text { Beyond High School } \ldots \ldots \ldots \ldots \ldots \ldots \ldots\end{array}$ & 77 & 81.9 & 49 & 84.5 \\
\hline 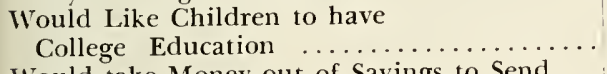 & 87 & 92.5 & 46 & 79.3 \\
\hline 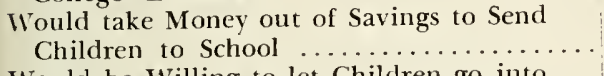 & 93 & 99.0 & 52 & 89.7 \\
\hline $\begin{array}{l}\text { Would be Willing to let Children go into } \\
\text { Debt in Order to get More Education ..... }\end{array}$ & 78 & 83.0 & 47 & 81.0 \\
\hline $\begin{array}{l}\text { Would be Willing to go into } \\
\text { Debt Myself } \ldots \ldots \ldots \ldots \ldots\end{array}$ & 88 & 93.6 & 51 & 87.9 \\
\hline Mean Score* & \multicolumn{2}{|c|}{$\begin{array}{c}\text { In-migrant } \\
36.7\end{array}$} & \multicolumn{2}{|c|}{$\begin{array}{c}\text { Native } \\
34.9\end{array}$} \\
\hline
\end{tabular}

*The value of the difference of the two percentages for samples of this size could happen only by chance less than one time in a hundred.

\section{Evaluation of Teachers}

As in the total sample, the parent group was asked to evaluate the teachers. Slightly more than half of the in-migrants and less than half of the natives said that the teachers were doing a good job, slightly over one-third of the new residents and less than half of the old said they were doing a fair job. The two groups hold very different views concerning the pay of teachers-43.1 per cent of the natives indicated that the teachers were paid too little, contrasted to 73.4 per cent of the in-migrants. Almost 60 per cent of the natives and 51.1 of the inmigrants indicated that the teachers were much better, or about the same as elsewhere (Table 16).

\section{Evaluation of the Schools}

As in the discussion of the total sample, the questions are consiclered here which elicited information concerning the respondents' evaluation of the schools. When asked if the schools needed improring, 92.6 per cent of the in-migrants and 79.3 per cent of the natives indicated that there is a great or moterate need for improvement. Over 


\section{Evaluations of Teachers by Parents of School Pupils, Jackson County, West Virginia, 1965}

\begin{tabular}{|c|c|c|c|c|}
\hline \multirow[t]{2}{*}{ Evaluation } & \multicolumn{2}{|c|}{$\begin{array}{c}\text { In-migrant } \\
\quad \mathrm{N}=94\end{array}$} & \multicolumn{2}{|c|}{$\begin{array}{l}\text { Native } \\
\mathrm{N}=58\end{array}$} \\
\hline & Number & Per Cent & Number & Per Cent \\
\hline $\begin{array}{l}\text { What Kind of job to You feel the } \\
\text { Teachers are Doing? ......... }\end{array}$ & & & & \\
\hline Good $\ldots \ldots \ldots \ldots \ldots \ldots$ & 50 & 53.5 & 25 & 43.1 \\
\hline Fair $\ldots \ldots \ldots \ldots$ & 33 & 35.1 & 25 & 43.1 \\
\hline Poor $\ldots \ldots \ldots \ldots$ & 8 & 8.5 & + & 6.9 \\
\hline 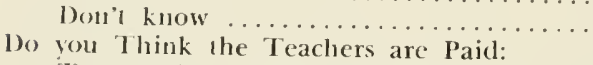 & 2 & 2.1 & 3 & 5.2 \\
\hline Too much or Right Anomit .... & 13 & 139 & 19 & 32.7 \\
\hline Too Little or Definitely Underpaid & 69 & 73.4 & 25 & 43.1 \\
\hline $\begin{array}{l}\text { Don's know ..................................... } \\
\text { Ihe Teachers of This County as Compared } \\
\text { with Elsewhere are: }\end{array}$ & 11 & 11.7 & 14 & 24.1 \\
\hline Much Better or About the Sane ...... & 48 & 31.1 & 34 & 58.6 \\
\hline Nor as Good or Definitely Worse. & 30 & 32.0 & 13 & 29.4 \\
\hline Don't know ................. & 15 & 16.0 & 10 & 17.2 \\
\hline
\end{tabular}

half of the natives, and one-third of the in-migrants, said the schools in Jackson County were much better, or about the same, as schools in neighboring counties in the State. In the comparison of the schools in the county with others in the United States, 58.5 per cent of the newcomers and 36.2 per cent of the old residents said they were not as good. When asked if they were dissatisfied with the schools, 69.1 per cent of the in-migrants and 37.9 per cent of the natives indicated that the? were. Educational standards in the county are low or average according to 65.5 per cent of the natives and 84.0 per cent of the newcomers (Table 17).

The attitudes toward the schools and teachers mean scores of the in-migrants and natives, 24.7 and 21.8 respectively, were found to be significantly different at the .0I level of significance. As in the total sample, the in-migrants were more dissitisfied with schools than were the natives.

\section{Rating of Provisions}

As above, the parent group was asked to evaluate school provisions. As might be expected, since this group has children in school, larger percentages of the respondents rated the provisions lower than did the total sample. However, the same trend appeared in these data-the in-migrants rated the provisions lower.

When asked to rate the school lunch program, both the newcomer and the old resident, 55.3 per cent and 56.8 per cent, respectirely, rated 


\section{Evaluation of Schools by Parents of School Pupils, Jackson County, West Virginia, 1965}

\begin{tabular}{|c|c|c|c|c|}
\hline \multirow[t]{2}{*}{ Evaluation } & \multicolumn{2}{|c|}{$\begin{array}{c}\text { In-migrant } \\
\mathbf{N}=94\end{array}$} & \multicolumn{2}{|c|}{$\begin{array}{l}\text { Native } \\
\mathrm{N}=58\end{array}$} \\
\hline & Number & Per Cent & Number & Per Cent \\
\hline Need for Improving the Schools: & & & & \\
\hline $\begin{array}{l}\text { Great or Moderate } \ldots \ldots \ldots \\
\text { Little or None } \ldots \ldots \ldots \ldots\end{array}$ & 87 & 92.6 & 46 & 79.3 \\
\hline $\begin{array}{l}\text { Little or None } \ldots \ldots \ldots \ldots \ldots \ldots \ldots \ldots \\
\text { Don't know } \ldots \ldots \ldots \ldots \ldots \ldots \ldots\end{array}$ & 3 & 3.2 & 3 & 5.1 \\
\hline & 3 & 3.2 & 3 & 13.8 \\
\hline \multirow{2}{*}{\multicolumn{5}{|c|}{$\begin{array}{l}\text { Comparison of Schools in Jackson County } \\
\text { with Schools in Neighboring Counties } \\
\text { in the State: . . . . . . . . . . . . . . }\end{array}$}} \\
\hline 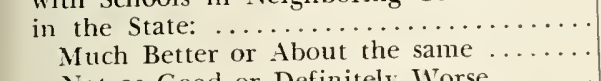 & & & & \\
\hline $\begin{array}{l}\text { Much Better or About the same } \ldots . . . \\
\text { Not as Good or Definitely Worse ..... }\end{array}$ & 28 & 29.8 & 34 & 51.7 \\
\hline $\begin{array}{l}\text { Not as Good or Definitely Worse } \ldots \ldots \\
\text { Don't know } \ldots \ldots \ldots \ldots \ldots \ldots \ldots \ldots\end{array}$ & 40 & 42.5 & 16 & 27.5 \\
\hline \multirow{2}{*}{\multicolumn{5}{|c|}{$\begin{array}{l}\text { Comparison of Schools in Jackson County } \\
\text { with Elsewhere in the United States: }\end{array}$}} \\
\hline & & & & \\
\hline Much Better or About the Same .... & 14 & 14.9 & 8 & 13.8 \\
\hline Not as Good or Definitely Worse & 55 & 58.5 & 21 & 36.2 \\
\hline 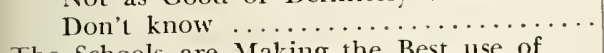 & 24 & 25.5 & 28 & 48.3 \\
\hline \multirow{2}{*}{\multicolumn{5}{|c|}{$\begin{array}{l}\text { The Schools are Making the Best use of } \\
\text { Money Available: }\end{array}$}} \\
\hline & & & & \\
\hline $\begin{array}{l}\text { Strongly Agree or Agree .... } \\
\text { Strongly Disagree or Disagree }\end{array}$ & 44 & 47.9 & 24 & 41.3 \\
\hline $\begin{array}{l}\text { Strongly Disagree or Disagree } \ldots \ldots \ldots \ldots \\
\text { Don't know } \ldots \ldots \ldots \ldots \ldots \ldots \ldots \ldots\end{array}$ & 35 & 37.2 & 20 & 34.5 \\
\hline $\begin{array}{l}\text { Don't know ............................. } \\
\text { Would you say That you are: }\end{array}$ & 13 & 13.8 & 13 & \\
\hline \multicolumn{5}{|l|}{$\begin{array}{l}\text { Would you say That you are: } \\
\text { Completely or Somewhat Satisfied with }\end{array}$} \\
\hline 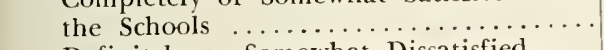 & 28 & 29.8 & 31 & 53.5 \\
\hline Definitely or Somewhat Dissatisfied. & 65 & 69.1 & 22 & 37.9 \\
\hline 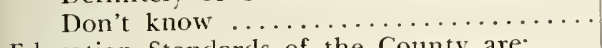 & 0 & 0.0 & 4 & 6.9 \\
\hline \multicolumn{5}{|l|}{ Education Standards of the County are: } \\
\hline High $\ldots \ldots \ldots \ldots \ldots \ldots \ldots \ldots \ldots \ldots$ & 7 & $\begin{array}{r}7.4 \\
57.4\end{array}$ & 33 & 56.9 \\
\hline Average $\quad \therefore \ldots \ldots \ldots \ldots \ldots \ldots$ & $\begin{array}{l}54 \\
25\end{array}$ & $\begin{array}{l}37.4 \\
23.6\end{array}$ & 5 & 8.6 \\
\hline $\begin{array}{l}\text { Low } \ldots \ldots \ldots \text {. } \\
\text { Don't Know. }\end{array}$ & 73 & 7.4 & 8 & 13.8 \\
\hline Don't Know. & & & & \\
\hline Mean Score* & & & & \\
\hline
\end{tabular}

*The value of the difference of the two percentages for samples of this size could happen only by chance less than one time in a hundred.

it as good. For the rating of transportation, over half of the natives and over one-third of the in-migrants inclicated a rating of fair to poor. While 38.3 per cent of the in-migrants rated the buildings as good, 36.8 per cent of the natives rated them the same. Almost six-tenths of the new residents and four-tenths of the old residents rated the range of subjects from fair to poor. Newcomers, 60.6 per cent, and 46.5 per cent of natives, indicated ratings of fair to poor for facilities. Slightly over 60 per cent of the in-migrants and nearly 50 per cent of the natives were dissatisfied with recreation in the schools (ratings of fair to poor) (Table 18). 
TABLE 18

\section{Ratings of School Provisions by Parents of School Pupils, Jackson County, West Virginia, 1965}

\begin{tabular}{|c|c|c|c|c|}
\hline \multirow[t]{2}{*}{ Rating of Provisions } & \multicolumn{2}{|c|}{$\begin{array}{c}\text { In-migrant } \\
\mathrm{N}=94 \\
\end{array}$} & \multicolumn{2}{|c|}{$\begin{array}{l}\text { Native } \\
\mathbf{N}=\mathbf{5 8}\end{array}$} \\
\hline & Number & Per Cent & Number & Per Cent \\
\hline \multicolumn{5}{|l|}{$\begin{array}{l}\text { Transportion } \\
\text { Good }\end{array}$} \\
\hline Good . & 44 & 46.8 & 24 & 41.3 \\
\hline Fair $\ldots \ldots \ldots \ldots \ldots \ldots$ & $2 I$ & 22.3 & 22 & 37.9 \\
\hline Poor $\ldots \ldots \ldots \ldots \ldots$ & 12 & 12.7 & 10 & 17.2 \\
\hline Don't know ............. & 16 & 17.0 & 1 & 1.7 \\
\hline \multicolumn{5}{|l|}{$\begin{array}{l}\text { School Lunch } \\
\text { Good }\end{array}$} \\
\hline Good $\ldots$ & 52 & 55.3 & 33 & 56.8 \\
\hline Fair .... & 25 & 26.6 & 12 & 20.7 \\
\hline Poor $\ldots$.... & 14 & 14.9 & 8 & 13.8 \\
\hline Don't know ....... & 2 & 2.1 & 4 & 6.9 \\
\hline \multicolumn{5}{|l|}{ Buildings } \\
\hline Good & 36 & 38.3 & 37 & 63.8 \\
\hline Fair .............. & 40 & 42.6 & 17 & 29.3 \\
\hline Poor $\ldots \ldots \ldots \ldots \ldots$ & 15 & 16.0 & 3 & 5.2 \\
\hline Don't know ............ & 2 & 2.1 & 0 & 0.0 \\
\hline \multicolumn{5}{|l|}{$\begin{array}{l}\text { Range of Subjects } \\
\text { Good }\end{array}$} \\
\hline Good $\ldots \ldots \ldots \ldots \ldots$ & 29 & 30.9 & 26 & 44.8 \\
\hline 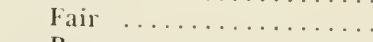 & 29 & 30.9 & 17 & 29.3 \\
\hline Poor $\ldots \ldots \ldots \ldots \ldots \ldots$ & 26 & 27.6 & 9 & 15.5 \\
\hline 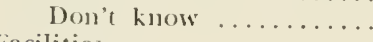 & 8 & 8.5 & 5 & 8.6 \\
\hline \multicolumn{5}{|l|}{ Facilities } \\
\hline Good $\ldots$ & 27 & 28.7 & 24 & 41.4 \\
\hline Fair ............ & 32 & 34.0 & 17 & 29.3 \\
\hline Poor $\ldots \ldots \ldots \ldots$ & 25 & 26.6 & 10 & 17.2 \\
\hline Don't know ... & 9 & 9.6 & 6 & 10.3 \\
\hline \multicolumn{5}{|l|}{ Recreation } \\
\hline Good . . & 25 & 26.6 & 26 & 44.8 \\
\hline Fair $\ldots \ldots \ldots \ldots$. & 41 & 43.6 & 14 & 24.1 \\
\hline Poor $\ldots \ldots \ldots \ldots$ & 16 & 17.0 & 13 & 22.4 \\
\hline Don't know $\because \ldots \ldots \ldots$ & 11 & 11.7 & 4 & 6.9 \\
\hline \multicolumn{5}{|l|}{$\begin{array}{l}\text { Vocational Eclucation } \\
\text { Good } \ldots \ldots \ldots \ldots\end{array}$} \\
\hline Good $\ldots \ldots \ldots$. & 20 & 21.2 & 20 & 34.5 \\
\hline Fair $\ldots \ldots \ldots \ldots$ & 17 & I 8.1 & 12 & 20.7 \\
\hline Poor .............. & 22 & 23.4 & 9 & 15.5 \\
\hline Don't know ......... & 34 & 36.2 & 16 & 27.6 \\
\hline
\end{tabular}

The in-migrants rather consistently rated the provisions lower than did the indigenous population. Therefore, it is evident that there is additional support for the data discussed above-the in-migrants are more dissatisfied with the school situation.

\section{Summary}

As in the total sample, the values and norms of the in-migrants and natives of the parent sample were found to be different. The inmigrants had more favorable attitudes about formal education, as shown in the frequency data. The attitude toward education mean 
scores of the in-migrants and natives, 36.7 and 34.9, respectively, was found to be significantly different.

Again, as in the total sample, the in-migrants were found to be more dissatisfied with the schools and teachers. The attitude toward the schools and teachers mean scores was found to be significantly different. The scores for the in-migrants and natives were 24.7 and 21.8, respectively.

The same trend appeared in the rating of provisions as it dicl in the total samples. The in-migrants rather consistently rated the school provisions lower than did the old residents.

\section{8}

\section{Introduction of Intervening Variables}

The analysis thus far has consistently indicated that the inmigrants have more favorable attitudes toward education and are more dissatisfied with the schools than is the indigenous population. At this point it becomes necessary to ask why the differences exist. Are they due to migration or are there other factors which contribute to these differences? In order to answer this question, the intervening variables of years of school completed and incomes of the respondent were introduced to standardize both the in-migrants and natives. Again, two samples were studied-the total and parents of school pupils. Two statistical tests were used in this particular analysis-students" " $\mathrm{t}$ " and the analysis of covariance.

The analysis of covariance was used to find the regression line most nearly common to both groups and was then used to test the significance to each regression line in terms of difference in slope. In Table 19 the $\mathrm{F}$ values for the slope and the mean for the total population and the pareni group are presented. In each instance but one, the means were found to be significantly different at the .05 level of significance. The attitude toward education means for the parent group, with the intervening variable of income, was very near significance, $\mathrm{P}<.06$. The $\log$ of income, as the intervening variable, for this same group was significant at the .05 level.

In only two instances, the attitude of the total population scores toward education with the variable of income controlled, and the 


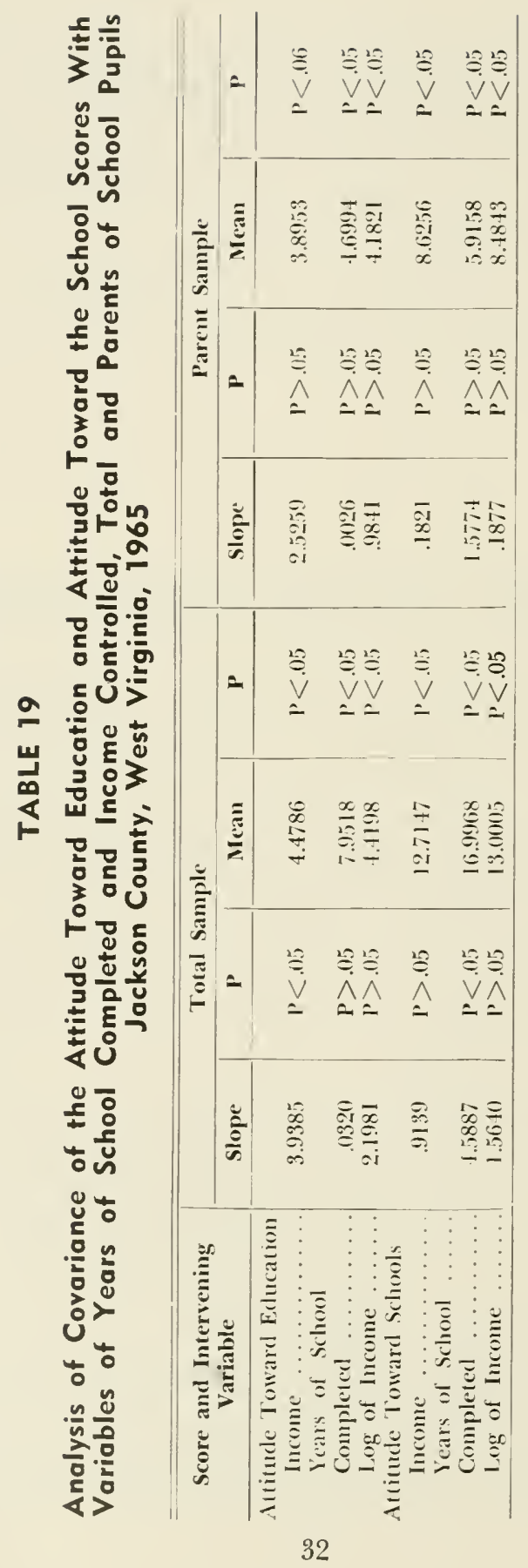


attitude of the total population scores toward the schools with the variable of education controlled, were the slopes found to be significantly different, $\mathrm{P}<.05$. In the remainder, the slopes were found to be equal (parallel). This means that a change in income or years of school completed results in a similar change in attitude toward education and attitude toward the schools scores for both groups. In other words, where the slopes are equal, but the means are different, there is an increase in the attitude toward education and the attitude toward the schools scores for a given rise in income, years of school completed, or log of income for each group. Since only two of the slopes were found to be significantly different for the total population, and none for the parent group, the two found to differ carry no real significance.

However, the difference in means specifies a difference between natives and in-migrants (at a given income or education level) as to the attitude toward education and attitude toward the schools.

In order to make the analysis more precise and to determine if there were any trends in the data at specific income and education levels, the " $\mathrm{t}$ " test was used. The analysis of covariance indicated that the means were significantly different but further analysis is needed to determine which means are significantly different.

A meaningful trend which appeared in the data was the difference in mean scores which occurred consistently at the lower income and education levels (under $\$ 4,000$ and less than 12 years of education). This held true, except in one instance, for both the total and parent samples in the attitudes toward education and the schools scores. The attitude toward education scores of the parent group at under $\$ 4,000$ income was near significance, $\mathrm{P}<.06$. The attitude toward schools scores of the total at over $\$ 4,000$ was found to be significantly different at the .01 level of significance, but since it was the only one in the upper income and education levels found to be different it does not assume significance. Since only one case was found not to be significant at the lower levels of income and education, and because this one was near significance, the trend is not changed. The in-migrant-native contrast in attitudes exists at the lower income and education Ievels but not at the higher. Therefore, the differences in the means as tested by covariance are primarily to differences within the lower socio-economic levels.

\section{Summary}

Since the differences between the in-migrants and natives were so significantly different, additional analysis became necessary. The variables of income and education were introduced to standardize both groups. 
The analysis of covariance indicated that the slopes were parallel in all but two cases. This indicates that the in-migrants and natives are similar in that a rise in income or elucation yields a subsequent rise in the score. However, since all the means but one were significantly different, the indication is that the two populations are different.

The " $t$ " test was used to determine which means were different at specific income and education levels. Therefore, the differences that were found to exist in the total and parent samples were due to differences at the lower income and educational levels.

\section{9}

\section{Participation in School Activities Of the Total Sample}

Data for this section were gathered in the survey and in informal interviews. The hypothesis to be tested is that a conflict of values resulted, and the in-migrants have sought to implement their values through lealership in the local P.T.A.'s, through working for congenial members of the school board, and through working for school levies.

\section{Participation in School Activities}

Questions were asked to elicit information as to the amount of participation in school activities. Relatively more in-migrants attend P.T.A. meetings than do natives, 61.5 per cent and 35.4 per cent, respectively. When the respondents were asked if they had worked for the election of certain school board members, more natives hach worked than had in-migrants (Table 20). Of the two groups visiting a meeting of the school board, 12.8 per cent were in-migrants and 11.8 were natives. When asked if they had worked for school levies, 36.4 per cent of the newcomers and 18.1 per cent of the natives responded that they had. A larger percentage of the natives than in-migrants indicated that they had roted in levy elections, 78.5 per cent and 72.8 per cent, respectively. Over half of the in-migrants, 62.2 per cent, indicated that they had discussed school programs with the teachers and principals and less than half of the old residents, 35.4 per cent, indicated the same. Of the in-migrants, 21.5 per cent said they had cliscussed school programs with the superintendent, as 
contrasted to 15.3 per cent of the natives. When asked if they discussed the quality of schools with friends and neighbors, 59.8 per cent of the natives and 81.4 per cent of the in-migrants said that they had.

TABLE 20

\section{Participation in School Activities by the Total Sample, Jackson County, West Virginia, 1965}

\begin{tabular}{|c|c|c|c|c|}
\hline \multirow[t]{2}{*}{ Participation } & \multicolumn{2}{|c|}{$\begin{array}{l}\text { In-migrant } \\
N=140\end{array}$} & \multicolumn{2}{|c|}{$\begin{array}{l}\text { Native } \\
N=144\end{array}$} \\
\hline & Number & Per Cent & Number & Per Cent \\
\hline Attendance at P.T.A. & & & & \\
\hline $\begin{array}{l}\text { Regularly } \\
\text { Occasionally }\end{array}$ & 32 & 22.9 & 20 & 13.9 \\
\hline $\begin{array}{l}\text { Occasionally } \\
\text { Never } \ldots . .\end{array}$ & 54 & 38.6 & 31 & 21.5 \\
\hline $\begin{array}{l}\text { Never } \ldots . . . \\
\text { Officer of P.T.A. }\end{array}$ & 51 & 36.4 & & 60.4 \\
\hline $\begin{array}{c}\text { Otficer of P.1.A. } \\
\text { Yes } \quad \ldots \ldots \ldots \ldots \ldots \ldots\end{array}$ & 21 & 15.0 & 14 & 9.7 \\
\hline No $\ldots \ldots \ldots \ldots \ldots$ & 113 & 80.7 & 125 & 86.8 \\
\hline \multicolumn{5}{|l|}{$\begin{array}{l}\text { Worked for the Election of } \\
\text { School Board Members }\end{array}$} \\
\hline $\begin{array}{l}\text { School Board Members } \\
\text { Did a Fair Amount }\end{array}$ & & & & \\
\hline $\begin{array}{l}\text { Did a Fair Amount } \\
\text { Worked a Little . }\end{array}$ & 8 & 5.7 & 12 & 8.3 \\
\hline $\begin{array}{l}\text { Worked a Little } \ldots \\
\text { Not at All } \ldots \ldots \ldots\end{array}$ & 19 & 13.6 & 18 & 12.5 \\
\hline $\begin{array}{l}\text { Not at All ......... } \\
\text { Visits to the Board }\end{array}$ & 111 & 79.3 & 110 & 76.4 \\
\hline \multicolumn{5}{|l|}{ Visits to the Board } \\
\hline $\begin{array}{l}\text { Two or More Times ... } \\
\text { Once } \ldots \ldots \ldots \ldots \ldots \ldots\end{array}$ & 9 & 6.4 & $\begin{array}{r}12 \\
5\end{array}$ & $\begin{array}{l}8.3 \\
3.5\end{array}$ \\
\hline $\begin{array}{l}\text { Once } \ldots \ldots \ldots \ldots \ldots \\
\text { Not at All } \ldots \ldots \ldots\end{array}$ & 9 & 6.4 & $\begin{array}{r}5 \\
124\end{array}$ & $\begin{array}{r}3.5 \\
86.1\end{array}$ \\
\hline $\begin{array}{l}\text { Not at All ............. } \\
\text { Worked for School Levies }\end{array}$ & 120 & 85.7 & 124 & \\
\hline Worked Very Hard ... & 16 & 11.4 & 9 & 6.3 \\
\hline Worked $\ldots \ldots \ldots \ldots \ldots \ldots$ & 35 & 25.0 & 17 & 11.8 \\
\hline Haven't Worked at All ..... & 86 & 61.4 & 116 & 80.6 \\
\hline \multicolumn{5}{|l|}{ Voting in Special Levy Elections } \\
\hline $\begin{array}{l}\text { All of These } \ldots \ldots \ldots \ldots \ldots \\
\text { Some } \ldots \ldots \ldots \ldots \ldots\end{array}$ & 85 & 60.7 & 77 & 53.5 \\
\hline $\begin{array}{l}\text { Some } \quad \ldots \ldots \ldots \ldots \ldots \ldots \\
\text { None } \quad \ldots \ldots \ldots \ldots \ldots \ldots \\
\end{array}$ & 17 & 12.1 & 36 & 25.0 \\
\hline $\begin{array}{l}\text { None } \ldots \ldots \ldots \ldots \ldots \ldots \\
\text { Discuss School Programs with }\end{array}$ & 32 & 22.9 & 29 & 20.1 \\
\hline \multicolumn{5}{|l|}{ Discuss School Programs with } \\
\hline $\begin{array}{l}\text { Teachers or Principal } \\
\text { Yes, Quite Frequently .... }\end{array}$ & & & & \\
\hline $\begin{array}{l}\text { Yes, Quite Frequently } \ldots . \\
\text { Yes, Sometimes ........... }\end{array}$ & 20 & 14.3 & 40 & 27.0 \\
\hline $\begin{array}{l}\text { Yes, Sometimes } \ldots \ldots \ldots \\
\text { No, not at All } \ldots \ldots \ldots \ldots\end{array}$ & 67 & 47.9 & $\begin{array}{l}40 \\
90\end{array}$ & $\begin{array}{l}27.8 \\
625\end{array}$ \\
\hline $\begin{array}{l}\text { No, not at All ........... } \\
\text { Discuss School Programs }\end{array}$ & 51 & 36.4 & & \\
\hline $\begin{array}{l}\text { Discuss School Programs } \\
\text { with Superintendent }\end{array}$ & & & & \\
\hline $\begin{array}{l}\text { with Superintendent } \\
\text { Yes, Quite Frequently }\end{array}$ & 11 & 7.9 & 4 & 2.8 \\
\hline Yes, Sometimes ....... & 19 & 13.6 & 18 & 12.5 \\
\hline 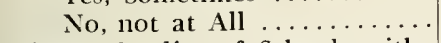 & 108 & 77.1 & 120 & 83.3 \\
\hline \multicolumn{5}{|l|}{ Discuss Quality of Schools with } \\
\hline Friends and Neighbors & & & & \\
\hline Yes, Very Much .. & 59 & 42.1 & 24 & 16.7 \\
\hline Yes, Sometimes ......... & 55 & 39.3 & 62 & 43.1 \\
\hline No not at All .......... & 24 & 17.1 & 56 & 38.9 \\
\hline Mean Score* & In- & rant & & \\
\hline
\end{tabular}

* The value of the difference of the two percentages for samples of this size could happen only by chance less than one time in a hundred. 
Although participation for both groups was low, as measured by the items in the schedule, a difference was found to exist. When testing the null hypothesis of no difference between the mean scores for participation, a significant difference was found at the .01 level, and the null hypothesis was rejected. The scores were 14.5 for the in-migrants and 13.0 for the natives, inclicating that the in-migrants participate more in schooi activities than do the natives.

\section{Summary}

The data support the hypothesis to be tested. The in-migrants rather consistently indicated responses that illustrate greater participation in school activities, as shown in the frequency data. Also, the significant difference found to exist between the mean scores is indicative of the different degrees of participation. The scores were 14.5 for the in-migrants and 13.0 for the natives. In the two items specifically mentioned in the hypothesis, that of attendance at P.T.A.'s and that of working for school levies, the in-migrants had a higher percentage of participation.

\section{0}

\section{Participation in School Activities by Parents of School Pupils}

\section{Participation in School Activities}

As in the total sample, the respondents answered questions conceming their participation in school activities. As might be expecterl, parti. cipation increased for both groups, but the differences still existed. Relatively more in-migrants had attended P.T.A. meetings than had the natives, 80.9 per cent and 51.7 per cent, respectively. The natives and in-migrants had clone approximately equal amounts of work for the election of school board members. Of the in-migrants, 17.0 per cent had visiteci a meeting of the school board and 20.7 per cent of the natives had done the same. When asked if thes had rorked for school levies, 13.6 per cent of the in-migrants and 22.4 per cent of the old residents responded that they had. Over 80 per cent of the wo groups indicated that they had voted in the lery elections. Slightly over 75 per cent of the newcomers and 48.3 per 
cent of the natives said that they had discussed school programs with teachers and principals. Of the in-migrants, 88.3 per cent, as contrasted to 70.7 per cent of the natives, indicated that they had discussed the quality of schools with friends and neighbors (Table 21).

\section{TABLE 21}

\section{Participation in School Activities by Parents of School Pupils, Jackson County, West Virginia, 1965}

\begin{tabular}{|c|c|c|c|c|}
\hline \multirow[t]{2}{*}{ Participation } & \multicolumn{2}{|c|}{$\begin{array}{c}\text { In-migrant } \\
\mathbf{N}=94\end{array}$} & \multicolumn{2}{|c|}{$\begin{array}{l}\text { Native } \\
\mathbf{N}=\mathbf{5 8}\end{array}$} \\
\hline & Number & Per Cent & Number & Per Cent \\
\hline $\begin{array}{r}\text { Attendance at P.T.A. } \\
\text { Regularly }\end{array}$ & & & & \\
\hline $\begin{array}{l}\text { Regularly } \\
\text { Occasionally }\end{array} \quad \ldots \ldots$ & 29 & $\begin{array}{l}30.9 \\
50.0\end{array}$ & $\begin{array}{l}12 \\
18\end{array}$ & 20.7 \\
\hline $\begin{array}{l}\text { Occasionally } \ldots \\
\text { Never } \ldots . . . .\end{array}$ & $\begin{array}{l}47 \\
17\end{array}$ & $\begin{array}{l}50.0 \\
18.1\end{array}$ & $\begin{array}{l}18 \\
28\end{array}$ & $\begin{array}{l}31.0 \\
48.3\end{array}$ \\
\hline Officer of P.T.A. & & & & \\
\hline Yes $\quad \ldots \ldots \ldots$ & 19 & 20.2 & 9 & 15.5 \\
\hline $\begin{array}{l}\text { No } \ldots \ldots \ldots \ldots \ldots \ldots \\
\text { Worked for the Election of }\end{array}$ & 73 & 77.7 & 49 & 84.5 \\
\hline \multicolumn{5}{|l|}{ Worked for the Election of } \\
\hline $\begin{array}{l}\text { Board Members } \\
\text { Did a Fair Amount of Work }\end{array}$ & & & & \\
\hline & 5 & $\begin{array}{r}5.3 \\
18.1\end{array}$ & $\begin{array}{l}5 \\
8\end{array}$ & $\begin{array}{r}8.6 \\
13.8\end{array}$ \\
\hline Not at All $\ldots \ldots \ldots \ldots \ldots$ & 71 & 75.5 & 44 & $\begin{array}{l}13.8 \\
75.9\end{array}$ \\
\hline \multicolumn{5}{|l|}{ Visits to the Board } \\
\hline Two or More Times & 8 & 8.5 & 9 & 15.5 \\
\hline Once $\ldots \ldots \ldots \ldots$ & 8 & 8.5 & 3 & 5.2 \\
\hline Not at All $\ldots . . .$. & 77 & 81.9 & 46 & 79.3 \\
\hline \multicolumn{5}{|l|}{ Worked for School Levies } \\
\hline Worked Very Hard & 14 & 14.9 & 7 & 12.1 \\
\hline Worked $\quad . . \ldots \ldots \ldots \ldots$ & 27 & 28.7 & 6 & 10.3 \\
\hline Haven't Worked at All .... & 52 & 55.3 & 45 & 77.6 \\
\hline \multicolumn{5}{|l|}{ Voting in Special Lery Election } \\
\hline All of These $\ldots \ldots \ldots \ldots$ & 66 & 70.2 & 36 & 62.1 \\
\hline Some $\ldots \ldots \ldots \ldots \ldots \ldots$ & 10 & 10.6 & 13 & 22.4 \\
\hline None $\ldots \ldots \ldots \ldots \ldots$ & 16 & 17.0 & 9 & 15.5 \\
\hline \multicolumn{5}{|l|}{ Discuss School Programs with } \\
\hline $\begin{array}{l}\text { Teachers or Principal } \\
\text { Yes, Quite Frequently ... }\end{array}$ & & & & \\
\hline $\begin{array}{l}\text { Yes, Quite Frequently ... } \\
\text { Yes, Sometimes .......... }\end{array}$ & 17 & $\begin{array}{l}18.1 \\
58.5\end{array}$ & 21 & $\begin{array}{l}12.1 \\
36.2\end{array}$ \\
\hline $\begin{array}{l}\text { Yes, Sometimes } \\
\text { No, not at All. }\end{array}$ & $\begin{array}{l}55 \\
21\end{array}$ & $\begin{array}{l}58.5 \\
22.3\end{array}$ & 29 & 50.0 \\
\hline \multirow{2}{*}{\multicolumn{5}{|c|}{$\begin{array}{c}\text { Discuss School Programs } \\
\text { with Superintendent }\end{array}$}} \\
\hline & & & & \\
\hline Yes, Quite Frcquently .. & 10 & 10.6 & 4 & 6.9 \\
\hline Yes, Sometimes & 16 & 17.0 & 10 & 17.2 \\
\hline 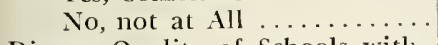 & 67 & 71.3 & 44 & 75.9 \\
\hline \multirow{2}{*}{\multicolumn{5}{|c|}{ Discuss Quality of Schools witl }} \\
\hline $\begin{array}{c}\text { Friends and Neighbors } \\
\text { Yes, Verv Much .... }\end{array}$ & & & & \\
\hline Yes, Very Much .. & 49 & 52.1 & 13 & 22.4 \\
\hline Yes, Sometimes … & 34 & 36.2 & 28 & $\begin{array}{r}48.3 \\
90.9\end{array}$ \\
\hline No, not at All. & 10 & 10.6 & 17 & 29.3 \\
\hline Mean Score* & In-1 & $\operatorname{rant}$ & & \\
\hline
\end{tabular}

*The value of the difference of the two percentages for samples of this size could happen only by chance less than one time in twenty. 
The increase in mean scores due to the elimination of those respon dents with no children in school was of no significance. The difference between the in-migrant and native scores was found to be significantly different at the .05 level. The mean score for the in-migrants was 15.7 , anc 14.2 for the natives.

\section{Summary}

The in-migrant and native parents of school pupils were also found to be different in the degree of school participation. The clata for both samples (total and parent) are comparable. The mean scores were also found to be significantly different $-\mathrm{P}<.05$. Therefore, it is clearly indicated that the in-migrants participate more in school activities than do the old residents.

\section{1}

\section{Introduction of Intervening Variables}

The participation scale involves more items than are mentioned in the sub-hypothesis. However, it includes two items mentioned thereinattendance at P.T.A. meetings and working for school levies. The items included in this scale offer a measure of participation in primary school activities.

As above, the intervening variable of income and years of school completed were introduced to standardize both groups. Again, the statistical tests used are the analysis of covariance and the " $\mathrm{t}$ " test.

In the analysis of covariance table (Table 22), participation scores (means) for each of the intervening variables were not significantly different. That is, the means were the same in both the total and parent samples. Also, the regression lines (slopes) of each were found to be the same (parallel).

When the two groups were standardized in regard to years of school completed and income, no differences existed. The two populations are the same in their patterns of participation in school activities. Since none of the means was significantly different in the analysis of covariance, the use of the " $t$ " test became unnecessary. 


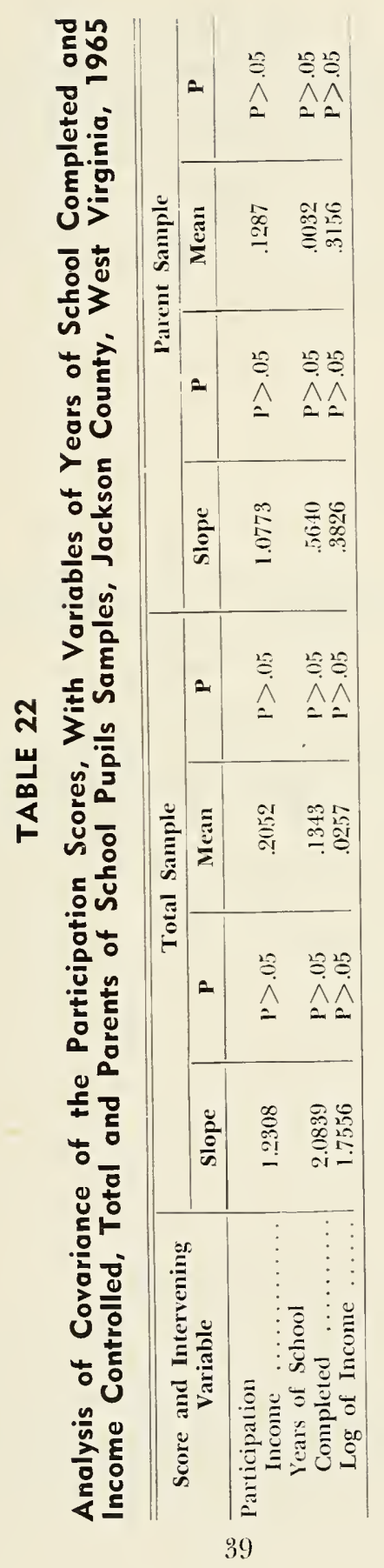




\section{Summary}

The analysis of covariance indicated that the populations are the same in regard to participation in school activities. The differences which were found to exist in the total and parent samples prior to introduction of the intervening variables, no longer are present. With standardization, the differences disappeared. However, even though the difference rias not statistically confirmed, belief persists in the county that the inmigrants participate more in school affairs.

\section{2}

\section{Respondents' Awareness}

\section{Total Sample}

In this part, two questions were asked to elicit information as to the respondents' awareness of persons and organizations that are active in working for better schools. Of the newcomers, 49.3 per cent mentioned one to two persons or groups and 39.6 per cent of the old residents indicated the same. Over 50 per cent of the natives and over 40 per cent of the in-migrants mentioned none (Table 23).

When asked the same question, but in reference to five years ago, 78.6 per cent of the in-migrants and 85.4 per cent of the natives knew of no persons or groups. A problem with the second question is that of recall. Many persons were unable to think of such persons or groups. Another, which might explain the high per cent of in-migrants indicating "don't knows" is that many were not living in the county five years before.

The indication is that the in-migrants are much more aware of persons and organizations that can get things done for the schools.

\section{Parent Sample}

In the parent groups, as above, questions were asked to determine the respondents' awareness. As might be expected, both groups had higher percentages of persons indicating active persons or organizations. However, the in-migrants had a markedly greater increase: 60.7 per cent indicated one to two persons or groups, as contrasted to 43.1 per cent of the natives (Table 24). 
It is strongly indicated, however, that the in-migrants are much more aware of aclive persons and organizations who (an help the schools.

\section{Summary}

These datil provide additional support for the sub-hypothesis. Although awareness is not a direct measure of participation, it indicates that the in-migrant is more concerned with the school situation than is the indigenous population. Almost 50.0 per cent of the in-migrants mentioned one or tro persons or groups but only 39.6 per cent of the natives did, for the total sample. In the parent sample the in-migrants, again, laad a higher percentage.

\section{3}

\section{Discussion of Informal Interviews}

From 1952 to the present, the people of Jackson County have facerl a constant problem of indelequate schools and educational facilities. The residents of the county during these years, and those who moved into the comnty during this period, inherited a lack of foresight in regard to education in the public schools.

Historically. Jackson County, like most counties in the State, had depended on the State for the bulk of elucational planning and support. The largely rural population considered the schools reasomably adequate. The unmet elucational needs, already consiclerable in 1952, were to reach gigantic proportions within the next few years.

School officials, a core of interested and progressive residents, and Kaiser itself have struggled hard through the recent years to meet the needs of an ever-growing school population and the problem of nonexistent or outmoded facilities.

With one major exception, repeated attempts to obtain finances to improve schools have met with failune. Comnty-wide recognition of the scope of the educational problems and willingness to do something about it have been notably lacking. In fact, the geographically larger part of the connty and the portion of the county in and about Ravenswood have developed a "split", that hampers solution of the educational problem.

In the live levy elections from 1955 to 1963 , as mentioned above, oni? one was passed (May 21, 1959). The only apparent reason for this one passing was because it was only a bond issue, and it offered something to, 
ust about every part of the county. Consistently, throughout these years he magisterial district of Ravenswood has voted in favor of these levies while the remainder of the county has voted against them. This adds ;upport to the sub-hypothesis, that a conflict of values has resulted. Since Ravenswood is heavily populated by newcomers, the voting pattern points up the conflict between the two groups.

The conflict is further illustrated by the formation of the Ravenswood Founclation to provide additional support for the schools in that part of the county. Kaiser offered to pay two dollars for every dollar obtained by the foundation, but Kaiser's amount was not to exceed $\$ 58,000$. The total amount collected reached $\$ 115,000$. The primary function of the foundation is to supply supplemental monies to the school board.

In each of the interviews with the newspaper editors, school board members, principals, and a few members of various organizations, a great deal of conflict was mentioned between Ravenswood and the rest of the county-conflict betwcen the new and old residents. When asked about participation in school activities, all confirmed the sub-hypothesis, but also indicated that many were young people and/or those with children. That is, those individuals with a direct interest are the ones who want better schools. One informant noted that there are three natives to one in-migrant in the county, but four natives to six in-migrants attending P.T.A. Relatively, more help is coming from the in-migrants. In most of the P.T.A.'s the in-migrants outnumber the old resiclents in both membership and leadership.

\section{4}

\section{Respondents' Opinions About People's Attitudes Toward the Schools}

\section{Total Sample}

The respondents were asked their opinions on the attitudes of the people toward education. The interviewees did not credit them with very favorable attitudes about formal education. Over 50 per cent of the in-migrants and less than 50 per cent of the natives indicated that the people in the county did not take enough interest in the schools. Both the newcomers and the old residents agreed that the people would not be in 
faror of an additional levy for schools, 69.3 per cent and 66.7 per cent respectively. When asked if the people would be in faror of an additionat lery for specific things such as better buildings, more facilities, mor subjects, hetter transportation. higher salaries for teachers, and a bette lunch program, the in-migrants consistently disagreed, all above 50 pe cent, and the natives disagreed also, but to a lesser degree, mostly les than 50 per cent (Table 25).

\section{TABLE 25}

\section{Respondents' Opinions About the People's Attitudes Toward the Schools, the Total Sample, Jackson County, West Virginia, 1965}

\begin{tabular}{|c|c|c|c|c|}
\hline \multirow[t]{2}{*}{ Opinion } & \multicolumn{2}{|c|}{$\begin{array}{c}\text { In-migrant } \\
I=140\end{array}$} & \multicolumn{2}{|c|}{$\begin{array}{l}\text { Native } \\
N=144\end{array}$} \\
\hline & Nimber & Per Cent & Number & Per Cent \\
\hline \multicolumn{5}{|l|}{$\begin{array}{l}\text { The Pcople Take Enough } \\
\text { Interest in Schools }\end{array}$} \\
\hline Yes $\ldots \ldots \ldots \ldots \ldots$ & 33 & 24.2 & 54 & 47.5 \\
\hline No $\ldots \ldots \ldots \ldots \ldots$ & 81 & 57.8 & 59 & $\$ 1.0$ \\
\hline $\begin{array}{l}\text {. Dot Sure ........................ } \\
\text { The People Would Support }\end{array}$ & 22 & $15 . \overline{7}$ & 25 & 17.4 \\
\hline an . Iclitional Lew for Schools & & & & \\
\hline les $\ldots \ldots \ldots \ldots \ldots \ldots \ldots$ & 16 & I1.4 & 16 & 11.1 \\
\hline No & 97 & 69.3 & 93 & 66.7 \\
\hline $\begin{array}{l}\text { Not sure .............................. } \\
\text { The People Would be in Favor of an }\end{array}$ & 24 & 17.1 & 28 & 19.4 \\
\hline \multicolumn{5}{|l|}{$\begin{array}{l}\text { The People Would be in Faror of an } \\
\text { Additional Ler! for Better Building, } \\
\text { Igre }\end{array}$} \\
\hline 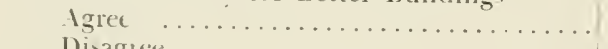 & 14 & 10.0 & I8 & 12.5 \\
\hline Disagree $\ldots \ldots \ldots \ldots \ldots \ldots \ldots \ldots \ldots \ldots \ldots$ & 86 & 61.5 & 78 & 54.2 \\
\hline 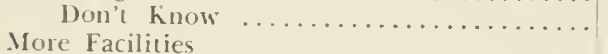 & 38 & $2-1$ & 44 & 30.6 \\
\hline $\begin{array}{l}\text { More Facilities } \\
\qquad \text { Igree } \quad \ldots \ldots \ldots \ldots\end{array}$ & \multicolumn{4}{|c|}{ More Facilities } \\
\hline Disagree $\ldots . . .$. & 79 & $\begin{array}{l}12.8 \\
56.4\end{array}$ & 25 & 17.4 \\
\hline Don't Know & 41 & $\begin{array}{l}56.4 \\
29.3\end{array}$ & 65 & 45.1 \\
\hline \multicolumn{5}{|l|}{ Higher Salaries for Teachers } \\
\hline Igree $\ldots . . \ldots \ldots \ldots$. & 21 & 15.0 & 31 & $2] .6$ \\
\hline Disagree $\ldots \ldots \ldots \ldots$. & 82 & 58.6 & 59 & 41.0 \\
\hline Don't Know & 34 & 24.3 & 50 & 34.7 \\
\hline \multicolumn{5}{|l|}{$\begin{array}{l}\text { More Subjects } \\
\text { Igree }\end{array}$} \\
\hline $\begin{array}{l}\text { Igree } \\
\text { Disagree }\end{array}$ & 22 & 15.7 & 26 & 18.1 \\
\hline $\begin{array}{l}\text { Disagree ... } \\
\text { Dont Know }\end{array}$ & 72 & 51.4 & 59 & 41.0 \\
\hline $\begin{array}{l}\text { Don t Know .... } \\
\text { Better Transportation }\end{array}$ & 44 & 31.4 & 55 & 38.2 \\
\hline \multicolumn{5}{|l|}{$\begin{array}{l}\text { Better Tiansportation } \\
\text { Igree }\end{array}$} \\
\hline $\begin{array}{l}\text { Igree } \ldots \ldots \ldots \\
\text { Disagree } \ldots \ldots\end{array}$ & 23 & 16.4 & 24 & 16.7 \\
\hline $\begin{array}{l}\text { Diragrce } \ldots \ldots \ldots \\
\text { Don't know . . . }\end{array}$ & 76 & 54.2 & 68 & 47.2 \\
\hline \multirow{2}{*}{\multicolumn{5}{|c|}{$\begin{array}{l}\text { Better Linch Program } \\
\text { Igree }\end{array}$}} \\
\hline Igree $\ldots \ldots \ldots \ldots \ldots$ & 23 & & & \\
\hline Disagree $\ldots .$. & 74 & 52.8 & 67 & $\begin{array}{l}1+.0 \\
46.5\end{array}$ \\
\hline Don't Know ............. & 41 & 29.3 & 52 & 36.1 \\
\hline \multirow{2}{*}{\multicolumn{5}{|c|}{$\begin{array}{l}\text { The People Would Favor Private } \\
\text { Sirpport for thools }\end{array}$}} \\
\hline & & & & \\
\hline$\ldots \ldots \ldots \ldots \ldots \ldots$ & 43 & 30.7 & 30 & 20.8 \\
\hline No $\ldots \ldots \ldots \ldots \ldots \ldots \ldots \ldots \ldots \ldots \ldots \ldots$ & 55 & 39.2 & 63 & 43.8 \\
\hline 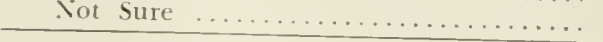 & 39 & 27.9 & 46 & 31.9 \\
\hline
\end{tabular}




\section{TABLE 26}

\section{Respondents' Opinions About the People's Attitudes Toward the Schools, Parents of School Pupils, Jackson County, West Virginia, 1965}

\begin{tabular}{|c|c|c|c|c|}
\hline \multirow[t]{2}{*}{ Opinion } & \multicolumn{2}{|c|}{$\begin{array}{c}\text { In-migrant } \\
\mathbf{N}=94\end{array}$} & \multicolumn{2}{|c|}{$\begin{array}{l}\text { Native } \\
\mathbf{N}=\mathbf{5 8}\end{array}$} \\
\hline & Number & Per Cent & Number & Per Cent \\
\hline $\begin{array}{l}\text { The People Take Enough Interest } \\
\text { in Schools: }\end{array}$ & & & & \\
\hline Yes $\ldots \ldots \ldots \ldots \ldots \ldots \ldots$ & 23 & 24.5 & 18 & 31.0 \\
\hline No $\ldots .$. & 62 & 66.0 & 32 & 55.2 \\
\hline Not Sure ................... & 8 & 8.5 & 7 & 12.1 \\
\hline $\begin{array}{l}\text { The People Would Support } \\
\text { an Additional Levy for Schools: }\end{array}$ & & & & \\
\hline 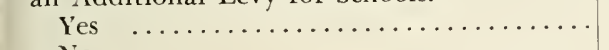 & 10 & 10.6 & 9 & 15.5 \\
\hline 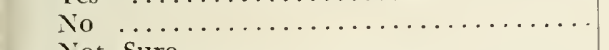 & 70 & 74.5 & 40 & 69.0 \\
\hline $\begin{array}{l}\text { Not Sure } \ldots \ldots \ldots \ldots \ldots \ldots \ldots \ldots \ldots \\
\text { The People Would be in Favor of }\end{array}$ & 13 & 13.8 & 8 & 13.8 \\
\hline $\begin{array}{l}\text { The People Would be in Favor of } \\
\text { an Additional Levy for Better Buildings }\end{array}$ & & & & \\
\hline 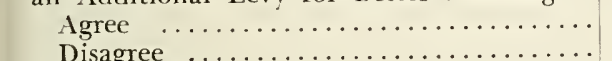 & 8 & 8.5 & 8 & 13.8 \\
\hline 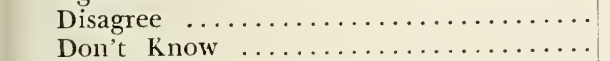 & 66 & 70.2 & 37 & 63.8 \\
\hline $\begin{array}{l}\text { Don't Know } \ldots \ldots \ldots \ldots \ldots \ldots \ldots \ldots \ldots \\
\text { More Facilities }\end{array}$ & 19 & 20.2 & 12 & 20.7 \\
\hline $\begin{array}{l}\text { More Facilities } \\
\text { Agree }\end{array}$ & & 128 & 12 & 207 \\
\hline $\begin{array}{l}\text { Agree } \quad \ldots \ldots \ldots \ldots \ldots \ldots \ldots \ldots \ldots \ldots \ldots \ldots \ldots \ldots \\
\text { Disagree } \quad \ldots \ldots \ldots \ldots \ldots \ldots \ldots \ldots \ldots\end{array}$ & $\begin{array}{l}12 \\
58\end{array}$ & $\begin{array}{l}12.8 \\
61.7\end{array}$ & $\begin{array}{l}12 \\
33\end{array}$ & $\begin{array}{l}20.7 \\
56.9\end{array}$ \\
\hline $\begin{array}{l}\text { Disagree } \ldots \ldots \ldots \ldots \ldots \ldots \ldots \ldots \ldots \ldots \ldots \ldots \\
\text { Don't Know } \ldots \ldots \ldots \ldots \ldots \ldots \ldots \ldots\end{array}$ & $\begin{array}{l}38 \\
23\end{array}$ & 24.5 & 12 & $\begin{array}{l}30.9 \\
20.7\end{array}$ \\
\hline Higher Salaries for & & & & \\
\hline $\begin{array}{c}\text { Teachers } \\
\text { Agree }\end{array}$ & 14 & 14.9 & 13 & 22.4 \\
\hline $\begin{array}{l}\text { Agree } \ldots \ldots \\
\text { Disagree } \ldots . .\end{array}$ & 63 & 67.0 & 30 & 51.7 \\
\hline Don't Know & 16 & 17.0 & 14 & 24.1 \\
\hline More Subjects & & & & \\
\hline Agree $\ldots$ & 17 & 18.1 & 15 & 25.9 \\
\hline Disagree $\ldots$ & 52 & 55.3 & 28 & 48.3 \\
\hline Don't Know... & 24 & 25.5 & 14 & 24.1 \\
\hline Better Transportation & & 139 & 14 & \\
\hline $\begin{array}{l}\text { Agree } \\
\text { Disagree }\end{array}$ & $\begin{array}{l}13 \\
58\end{array}$ & $\begin{array}{l}13.9 \\
61.7\end{array}$ & 31 & $\begin{array}{l}24.1 \\
53.4\end{array}$ \\
\hline $\begin{array}{l}\text { Disagree ... } \\
\text { Don't Know }\end{array}$ & $\begin{array}{l}58 \\
22\end{array}$ & 23.4 & 12 & $\begin{array}{l}53.4 \\
20.7\end{array}$ \\
\hline $\begin{array}{l}\text { Don't Know ...... } \\
\text { Better Lunch Program }\end{array}$ & & & & \\
\hline $\begin{array}{c}\text { Better Lunch Program } \\
\text { Agree } \quad \ldots \ldots \ldots \ldots\end{array}$ & 16 & 17.1 & 13 & 22.4 \\
\hline $\begin{array}{l}\text { Agree } \ldots \ldots \ldots \ldots \\
\text { Disagree } \ldots \ldots \ldots\end{array}$ & 55 & 58.5 & 31 & 53.4 \\
\hline Don't Know .............. & 22 & 23.4 & 13 & 22.4 \\
\hline The People Would Favor Private & & & & \\
\hline Support for Schools & 29 & 30.9 & 16 & 27.5 \\
\hline 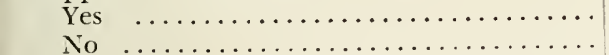 & $\begin{array}{l}29 \\
42\end{array}$ & 44.7 & 28 & 48.3 \\
\hline 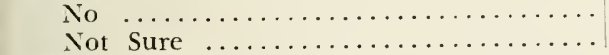 & 22 & 23.4 & 13 & 22.4 \\
\hline
\end{tabular}

Although specific data are not available, the in-migrants made a qualification before answering-the qualification being that Ravenswood would be in favor of additional levies, but the county as a whole would not be. 


\section{Parent Sample}

As above, the respondents were asked to give their opinions of how others felt about education. Again, the respondents did not credit thei comterparts in the county with holding very favorable attitudes abou education. Over 60 per cent of the in-migrants and over 50 per cent of the indigenous population indicited that the people do not take enough in terest in the schools. The belief that people would not support an additional levy was held by 74.5 per cent of the newcomers and 69.8 per cent of the old residents. When asked if the people would be in favor of a levy for better buildings, more facilities, higher salaries for teachers, more subjects, better transportation and better lunch programs, almost 60 per cent of the in-migrants and slightly over 50 per cent of the natives thought not (Table 26).

\section{Summary}

The interviewees do not credit others with holding very favorable attitudes about formal education. In both the total and parent samples, the in-migrants have stronger negative feelings about the people of Jackson County. 


\section{5}

\section{Conclusions}

The following conclusions are based on evidence gathered in the Jackson County study, relating to attitudes toward education and the schools. This study compared the attitudes of the in-migrants with those of the older residents in a rural, recently industrialized community.

The basic hypothesis that the in-migrants brought into the county different educational values and norms was partially upheld. For the total and parent samples, the in-migrants were found to have different values and norms as presented in the survey clata. The attitude toward education and the attitude toward the schools scores were found to be significantly different, $\mathrm{P}<.01$.

In order to determine why the differences existed, the variables of years of school completed and income were controlled. The trend that appeared after the analysis of these data was that differences existed only at the lower income and education levels. This evidence indicates that migration is a factor in the differences only at the lower socio-economic levels; the differences do not exist at the upper levels.

The main sub-hypothesis that a conflict of values resulted and that the in-migrants have sought to implement their values through leadership in the local P.T.A.'s, through working for congenial members of the school board, and through working for school levies was also partially upheld. The in-migrants were found to participate more in school activities than did the indigenous population. The participation mean scores for the total and parent samples were found to be significantly different. However, when the variables of years of school completed and income were controlled, the difference no longer existed.

Belief persists in the county that the in-migrants participate more in school affairs. The informal interviews with knowledgeable people in the county consistently confirmed that there was a conflict of values between the in-migrants and natives and that the in-migrants participate more in school activities. This conflict is also evident in the respondents' opinions about the people's attitudes toward the schools. Both groups had negative opinions about the people's attitudes. However, the in-migrants' feelings were more negative. This indicates a certain amount of frustration on the part of the in-migrants in their adjusting to the school situation. 
Since this study took place approximately seven years after the col struction of the Kaiser plant, the population of the county seemed t be relatively homogenous. The slight differences that now exist migh have been greater five years ago. 

